\title{
11. Bacterial Pathogens in Seafood
}

\author{
R J Lee and R E Rangdale, Centre for Environment, Fisheries and Aquaculture Science, UK, \\ L Croci, Istituto Superiore di Sanità, Italy, \\ D Hervio-Heath and S Lozach, Ifremer, France
}

\subsection{General introduction}

A number of bacterial illnesses may arise from the consumption of seafood that has either been contaminated at source or which becomes contaminated during the processing and retail chain. Such illnesses may arise from infection with the bacteria themselves or by the ingestion of toxins formed in the foodstuff prior to consumption. This division is actually too simplistic: for example, the toxins of Clostridium botulinum and Staphylococcus aureus are preformed in food during bacterial growth, the toxin of Clostridium perfringens is usually only formed when the bacteria sporulate in the intestinal tract while the toxin of Vibrio cholerae O1 (and O139) is produced when the bacteria multiply in the intestinal tract.

One of the most common illnesses associated with seafood is scombrotoxin, due to the production of histamine, and possibly related compounds, by certain types of Gram-negative bacteria growing on histidine rich fish tissue. This subject is explored in more detail in another chapter in this book and therefore it will not be considered in depth here.

This chapter will consider the range of bacteria that may cause illness in humans following seafood consumption, the incidence of such infections that are reported in certain countries for which the data is available, and will review conventional and molecular techniques for the detection, identification and typing of the bacteria. There is increasing interest in the vibrios as agents of bacterial illness associated with the consumption of bivalve molluscan shellfish and other types of seafood and particular attention will be paid to this group of bacteria.

\subsection{Principal bacterial pathogens associated with seafood}

The principle bacterial hazards associated with seafood are shown in Table 11.1. 
In general, the bacterial hazards associated with seafood consumption, apart from the specific case of the marine vibrios pathogenic for humans, does not differ significantly from those associated with other foods. Some types of seafood, such as bivalve molluscs eaten raw (principally oysters), other raw seafood, or fermented seafoods, pose particular problems.

Invasive listeriosis is a severe disease mainly associated with a specific risk group of people (Crum, 2002). It causes meningitis, encephalitis, bacteremia, and febrile gastroenteritis. Most disease occurs in immunosuppressed individuals. The organism occurs widely in the environment. Although there is a large concentration on testing of seafood products for Listeria monocytogenes, and some other Listeria spp., the level of risk associated with this organism from seafood consumption is probably small - the US risk assessment on $L$. monocytogenes only identified four seafood associated outbreaks worldwide in the period 1970-2000, one associated with raw seafood, one with smoked seafood and two with smoked mussels (FDA, 2003).

Table 11.2 gives some of the principal clinical features of the illnesses caused by these organisms, together with the principal sources. The latter is discussed further in Section 11.3.

\subsubsection{Vibrios involved in food poisoning}

Vibrios are Gram-negative bacteria that are primarily associated with estuarine and coastal marine environments. A number of species have been associated with intestinal or extraintestinal infections in humans. All vibrios have an absolute requirement for $\mathrm{Na}^{+}$for growth although some, such as $V$. cholerae only require trace amounts. The surface and intestinal microbial flora of harvested fish and shellfish, particularly those from brackish, estuarine and 
coastal environments, will tend to contain high numbers of members of the genus Vibrio. Only a small proportion of the vibrios present will belong to species that may be pathogenic in humans and, of these, only a small proportion of the isolates of such species may possess the pathogenicity traits that enable them to colonise and cause disease in the human body.

Doubling time of vibrios under ideal conditions may be as short as 10 minutes or less, but usually much longer in seafoods at ambient temperature. Little growth of pathogenic vibrios usually occurs in seafood stored below $10^{\circ} \mathrm{C}$. A one-log reduction of pathogenic vibrios in seafoods takes between 1 and 10 minutes at $50^{\circ} \mathrm{C}$, depending on species and strain. Vibrios die out gradually at refrigeration temperatures and numbers are markedly reduced by freezing and thawing.

Marine vibrios naturally contaminating bivalve molluscs have also been shown to be less easily removed by depuration than are faecal bacterial indicators such as E. coli (Rodrick and Schneider, 1991). Such processing methods may therefore not provide the necessary level of public health protection if significant levels of pathogenic vibrios are present in harvested product.

The infectious dose of human pathogenic marine vibrios may be relatively high (Sanyal and Sen 1974) and therefore the presence of low numbers in final product may therefore not be of significance. It is also known that strains of the potentially pathogenic species vary in their pathogenicity. Only a small proportion of the vibrios present will belong to species that may be pathogenic in humans and, of these, only a small proportion of the isolates of such species may possess the pathogenicity traits that enable them to colonise and cause disease in the human body. These factors enhance the difficulty of isolating potentially pathogenic Vibrio 
spp from seafoods and also in fully determining the potential significance of those that are detected.

Further information may be found in the US risk assessment on $V$. parahaemolyticus (FDA 2005), the European Commission report on V. parahaemolyticus and Vibrio vulnificus in seafood (European Commission 2001) and the FAO/WHO risk assessments on V. vulnificus (FAO/WHO 2005a) and V. cholerae (FAO/WHO 2005b).

Vibrio cholerae

Epidemic and pandemic cholera is associated with toxigenic strains of Vibrio cholerae $\mathrm{O} 1$ and O139. The toxin is produced in the intestine during multiplication and causes marked loss of fluid into the intestine, resulting in extremely watery diarrhoea which leads to extreme dehydration and, if not treated, to death. Contamination of seafood is usually either by faecal contamination of the marine environment or by contact with faecally contaminated fresh water during preparation of the food. Vibrio cholerae serotypes other than $\mathrm{O} 1$ and $\mathrm{O} 139$ may be pathogenic. Some may be able to produce cholera toxin but lack the ability to produce epidemics and pandemics. Although $V$. cholerae $\mathrm{O} 1$ and $\mathrm{O} 139$ infections are potentially severe, and the public health consequences of epidemics may be grave, infections due to other $V$. cholerae serotypes are much more commonly associated with seafood and, in general, cause a much higher level of morbidity and mortality from this source.

Vibrio cholerae $\mathrm{O} 1$ outbreaks have also been reported in association with raw shellfish consumption (Baine, et al., 1974) or raw seafood or cooked crab (Weber et al., 1994). Whereas contamination with other vibrios arises from bacteria naturally present in the marine 
environment, that with $V$. cholerae, in particular serovar O1, may be associated with faecal contamination. V. cholerae non-O1 serotypes have also been reported from the marine environment in the UK, France and Italy (Bashford, et al., 1979; Hervio-Heath et al, 2002; Demontet et al., 2002).

\section{Vibrio parahaemolyticus}

Vibrio parahaemolyticus food-poisoning associated with seafood consumption has been identified in many countries (Blake, et al., 1980). Food-poisoning with this organism is most commonly reported from countries with both a high ambient temperature and where seafood is consumed raw. Seafoods which may be associated with human infection due to $V$. parahaemolyticus are bivalve molluscs, finfish and crustacea, particularly those served raw or superficially cooked and which have been exposed to temperature abuse (see below). In Europe, the main type of seafood eaten raw or lightly cooked are species of bivalve molluscan shellfish and thus arguably bivalve molluscs, such as oysters and mussels, constitute a risk to the European consumer. V. parahaemolyticus can be commonly isolated from estuarine environments that form suitable habitats for the growth of a variety of shellfish species and it has been shown to be present in the marine environment of several European countries, including the UK (Ayres and Barrow, 1978), France (Hervio-Heath et al. 2002), Spain (Lozano-León et al. 2003), Italy (Cavallo and Stabili, 2002) and Greece (Davies et al., 2001). There is a well-recognised correlation between pathogenicity of $V$. parahaemolyticus isolates and their ability to form Thermostable Direct Haemolysin (TDH) or TDH-Related Haemolysin (TRH) (Takeda 1983; Honda and Iida 1993). However, the presence of $V$. parahaemolyticus in the absence of thermostable haemolysins may not represent a pathogenic risk as the proportion of strains isolated from environment possessing the ability to produce these putative pathogenicity principles is reportedly low (Nishibushi 
and Kaper 1995). For example, in the United States, only $0.2-3.2 \%$ of environmental isolates of $V$. parahaemolyticus isolates contain the $t d h$ gene which is associated with the potential to cause gastro-enteritis in humans, with the proportion varying by geographical region (FDA 2001). Currently in Europe the prevalence and distribution of TDH and TRH producing $V$. parahaemolyticus in the marine environment or indigenously produced seafoods is not known.

Vibrio vulnificus

Vibrio vulnificus, is associated with significant mortality in persons with underlying predisposing illness who consume raw shellfish or who are subject to contamination of open wounds by seawater. These predisposing conditions include liver disease, diabetes mellitus and immunodeficiency (including that caused by AIDS). Illness caused by consumption of raw oysters usually manifests as a primary septicaemia, where the systemic illness is not preceded by any apparent localised infection - i.e. there may not be any gastrointestinal symptoms. The mortality rate is approximately 50\%. Reports of infection with this organism have originated mainly from the United States but there have also been isolates in other parts of the world (Hlady 1997, Chuang, et al., 1992). In Europe, V. vulnificus has been reported as having been isolated from mussels in Denmark (Hoi, et al., 1998) and France (HervioHeath et al., 2002) and from cutaneous infections in Scandinavia and the Low Countries (Melhus, et al., 1995; Veenstra, et al., 1993).

\section{Other Vibrio spp.}

Vibrio mimicus is a bacterium that resembles Vibrio cholerae in many characteristics, including its ability to grow in low concentrations of sodium and its antigenic structure. It has 
been implicated in individual cases and outbreaks of gastroenteritis and some strains can also produce cholera toxin.

Vibrio fluvialis is an inhabitant of estuarine and coastal waters and has been identified as causing individual cases and outbreaks of gastroenteritis. As with many other vibrios, infection is usually associated with the consumption of raw or undercooked seafood, especially raw oysters.

Vibrio furnissii is closely related to Vibrio fluvialis both genetically and phemnotypically. However, it has been isolated much more rarely from faecal samples of patients with gastroenteritis and so there is some doubt as to its significance as a seafood-associated pathogen.

Vibrio hollisae is a marine vibrio that has been reported to cause gastro-enteritis following consumption of raw shellfish. The significance of this vibrio is difficult to estimate because of its failure to grow on conventional vibrio media (Morris, et al., 1982).

11.3 Sources of bacterial pathogens in seafoods

\subsubsection{Contamination at source}

Contamination of seafood with bacterial pathogens at source (i.e. in the sea) primarily arises from two different origins.

The first with bacteria that occur naturally in the marine environment which, when consumed in seafood in large enough numbers, will cause illness in humans. This primarily relates to 
the vibrios. Some species of the genus Aeromonas are considered to some to possibly cause gastro-enteritis in humans and these may also be present naturally in the marine or, more especially, the estuarine environment.

Spores of type F Clostridium botulinum are found widely in marine sediments and the intestinal tract of fish and shellfish and, if seafood is stored under conditions (principally in the absence of oxygen) that allows the spores to germinate and the bacteria to multiply, toxin may be formed in the seafood and then cause botulism in humans when the food is consumed.

The other source of contamination is from faecal contamination of the marine environment. This may arise from contamination with human faeces from sewage discharges, boats and ships or, in some countries, direct defaecation into the marine environment or rivers and streams flowing into it. Some bacteria may also arise from the contamination of the marine environment by animal faeces. Again, this may arise from discharges from animal keeplots or slurry pits, or direct defaecation into the marine environment or rivers or streams flowing into it. Some bacteria, such as Salmonella Typhi and Vibrio cholerae, are principally associated with human faecal contamination while non-typhi Salmonella and Campylobacter, may arise from either source. Seafood harvested from such environments may constitute a risk if:

- The bacteria are they are initially present in sufficient numbers that they exceed the infectious dose

- or the seafood is stored under conditions that allow a lower initial concentration to multiply to the point where the bacteria exceed the infectious dose

- and, if any control measures are applied, they are not sufficient to reduce to, or maintain the bacterial concentration, at a low enough level. 
Similar criteria apply to the production of toxin by toxin-forming bacteria.

In general, contamination at source is a greater problem with respect to bivalve molluscs than other seafoods due to their filter-feeding activities which tend to concentrate pathogens within the gut of the bivalves. Following harvest, these tend to be eaten raw or lightly cooked, thus potentially allowing the survival of any pathogens present in the bivalves at harvest.

The issue of temperature control following harvesting is particularly important with respect to the risk of illness from pathogenic vibrios. In the USA, it has been shown that the cooling time and subsequent time and temperature of transport and storage are significant risk factors with respect to $V$. parahaemolyticus infection from oysters FDA, 2005). In Europe, it is not the norm for bivalve molluscs to be refrigerated between harvest and either depuration or dispatch.

\subsubsection{Cross-contamination}

Cross-contamination may take place in the processing environment or during food preparation prior to consumption. Such contamination may be from the environment to the food, from a contaminated food batch or item to a previously uncontaminated one, or from an infected food handler to one of more items of food. Some pathogenic bacteria can become established in the processing environment and, if not eradicated, can be a long-term source of contamination of batches. This applies particularly to L. monocytogenes in fishery product establishments (Miettinen, 2006). Once this organism becomes established in a factory it can be difficult to remove by normal cleaning procedures.

As noted above, live bivalve molluscs, being contained in their shells, are generally less prone to cross-contamination than other seafoods. However, if several batches of bivalves 
from different areas are immersed in the same seawater tank(s), during either wet storage or depuration, then cross-contamination may occur from one batch to another. Contamination may also arise if the seawater itself is not of sufficient initial quality, or is not otherwise properly treated prior to use. Salmonella spp. has been shown to be viable after excretion in oyster faeces (Rowse and Fleet, 1982).

A potential route of contamination of cooked crustacea and bivalve molluscs is the use of untreated seawater for cooling the shellfish following the cooking process (European Commission, 2001). This procedure is particularly prone to take place when cooking is undertaken on board boats.

\subsection{Control of bacterial contamination}

The pursuit of a high level of protection of human life is the fundamental objective of Regulation (EC) No 178/2002, which prohibits the placing on the market of unsafe food and provides a uniform basis for the use of the precautionary principle.

To this aim Regulation (EC) No. 852/2004 lays down general rules for food business operators, which have the primary responsibility for food safety, that must be assured throughout the food chain, starting with primary production, by means of the implementation of procedures based on HACCP principles, together with the application of good hygiene practice (GHP).

Besides the Regulation (EC) No. 853/2004 lays down specific hygiene rules, necessary for certain foodstuffs, that shall be applied to unprocessed and processed products of animal origin. 
Then on the basis of the Regulation (EC) 854/2004, laying down specific rules for official controls on foodstuff animal origin, the Competent Authority of the Member States must carry out inspections to control the observance of the quality criteria of the products to assure the health of the consumer. Microbiological standards are established by the Regulation (EC) No.2073/2005, foods not meeting a standards are in noncompliance and in this case the regulatory control actions may lead to sorting, reprocessing, rejection or destruction of product, and/or further investigation to determine the appropriate actions to be taken.

Microbiological limits should be appropriate for the food and be applicable at one or more points in the food chain. Limits for specific hazards should be compatible with any FSOs (Food Safety Objective) that may have been established.

In particular for the microbial contamination of the seafood it must be considered that the dominant population of bacteria on finfish and shellfish is mainly composed of saprophytic species, however the level of contamination of living fish with bacteria of public health significance can vary greatly among the localities. Molluscan shellfish are normally considered separately from the other seafood because of their different physiologies, modes of life, feeding and handling/processing requirements after harvest.

\subsubsection{Harvesting, handling and transport}

Fresh fishery products. Finfish are caught in areas more or less remote from the processing plants. After capture, to ensure microbiological quality and safety, they must be protected from spoilage during the transport to the processing plant, that can vary from a few hours to some weeks. Beneficial effects on storage life can be obtained reducing the bacteria number or preventing the flesh contamination. Finfish may be eviscerated on board of the vessel and as the contamination of fish from handling and storage procedures can affect subsequent 
storage (Ward and Baj, 1988) the operations such as heading and gutting must be carried out hygienically and as quickly as possible. The products must be washed thoroughly with potable water or, on board vessels, clean water immediately after these operations. Containers used for the dispatch or storage of unpackaged prepared fresh fishery products stored under ice must ensure that melt water does not remain in contact with the products. On board vessels and after landing the products must be transported in cooled water until the first establishment. Food business operators must ensure all these requirements according to the Regulation (EC) No.853/2004.

\section{Live bivalve molluscs}

Live bivalve molluscs must be harvested only from areas that Competent Autority has classified as being of class A, B, or C in accordance with Regulation (EC) No. 854/2004. Classification is based on levels of E. coli in bivalves in the harvesting area as an indicator of the risk of the presence of pathogens associated with faecal contamination. Recommendations for such monitoring have been produced by a European Working Group (CRL 2007). Bivalve molluscs collected from class B or C production areas may be placed on the market for human consumption, only after a purification treatment performed respectively in a purification centre or after relaying over a long period in accordance with Regulation (EC) No. 853/2004. Purification was originally developed for the removal of $S$. Typhi from bivalve molluscs: it has been reported that $0.1 \%$ of the original concentration of salmonella remains in clams after 24 hours purification (Timoney \& Abston, 1984). Oysters naturally contaminated with pathogenic oysters were found to retain a significant proportion (44\%) after 2 days purification and therefore the process is not effective in removing all types of bacterial pathogens (Jones et al., 1995). Long-term relaying is intended to remove viral contamination. However, relaying in high salinity seawater (>30 parts per thousand) has been 
suggested as a way of removing pathogenic vibrios from bivalves (Motes and DePaola, 1996).

During all production process food operators must use harvesting techniques and further handling that not cause additional contamination or damage to the animals, adequately protecting them from crushing, abrasion or vibration and not exposing to extreme temperatures or re-immersing them in water that could cause additional contamination.

After harvesting or treatment food business operators storing and transporting live bivalve mollusks must ensure that they are kept at a temperature that does not adversely affect food safety or their viability. The products must not be re-immersed in, or spayed with, water after they have been packaged for retail sale and left the dispatch centre.

\subsubsection{HACCP plans}

Food operators have the responsibility to apply, along the food chain, a series of control measures that contribute to providing safe products. These measures, applied at different steps of the production, aimed to eliminate, prevent or reduce the hazard to an acceptable level, according to the GHP and HACCP programs.

The first, GHP program, based on the application of the basic hygienic practices, also includes other activity as raw material selection, lot identification, product information, labeling, consumer education, handling/ storage instructions and so on. Its application provides the foundation for HACCP systems.

\subsubsection{Failure of control measures}

With fishery products, there are two principal ways that failure may occur in such a way as to affect the bacteriological quality of the product. The first is a failure to maintain adequate 
temperature control which may allow proliferation of bacteria in the product. These bacteria may be pathogens, in which case illness may ensue if the resulting concentrations exceed those needed to initiate infection. If the bacteria are non-pathogens, the failure of temperature control may result in spoilage. The failure in temperature control may be at any point along the chain after harvest. However, in order to increase the risk of illness, the failure must be after the stage at which pathogens were first present in the product. The exact point at which this occurs is not always evident. The second way is by cross-contamination as outlined in section 11.3.2. Such cross-contamination may occur at any point post-harvest but is often associated with contamination at the production plant or during food preparation. There is obviously the possibility of both events occurring: cross-contamination introducing a pathogen to the product and inadequate temperature control exacerbating the risk by allowing multiplication of the pathogen.

The toxin of Clostridium botulinum is formed when the organism multiplies under the right conditions. Two principal food processes are associated with botulism. One is canning when insufficient heating during the canning process leaves spores which can then grow in the anaerobic conditions in the can. The other is fermentation of fish products, especially when whole or inadequately cleaned fish are fermented for prolonged periods of time to form fish products or sauces.

Salmonella infection primarily occurs due to the consumption of undercooked food contaminated at the time of harvest or by cross-contamination after cooking. The risk of infection is increased by the storage of cooked food at ambient temperature prior to consumption.

The assessment of risk associated with bivalve mollusc harvesting areas based on $E$. coli monitoring depends partly on the design and implementation of the monitoring programme 
(Younger, Lee and Lees, 2003). There is no relationship between faecal indicators and the presence of pathogenic vibrios, not even Vibrio cholerae (European Commission 2001), and therefore classification does not reflect the risk from these pathogens.

In general, the European legislative controls on commercially produced bivalve molluscs have addressed the problems of bacteria associated with faecal contamination that can arise from consumption of this type of seafood. However, this does not address bivalves gathered by family groups for their own consumption. Also, unfortunately, bivalves for commercial sale may not fully comply with the legislative requirements, either by intent or by ignorance. An example of this is an outbreak of Salmonella in the UK was due to cockles which had been harvested from an unclassified area and had been inadequately cooked in a domestic environment before sale (Grennwood et al., 1998).

\subsection{Seafood-associated bacterial illness}

The level of epidemiological reporting of seafood-associated illness varies markedly between different countries. Reporting of internationally notifiable illnesses, such as cholera and typhoid, may be expected to be more consistent, but even this can be subject to political interference as countries may not wish to be identified as having such a disease. This means that global, and even regional, illness statistics related to seafood consumption are not reliable. Even within individual countries, several factors affect the level of reporting and complicates the assessment of outbreak data (O’Brien et al., 2002). This also means that the statistics from individual countries will not be comparable. However, comparison of data from countries with relatively good reporting systems will give an impression of the problems and the relative risk from the consumption of different seafoods. 
Epidemiological data usually relates to the reporting of outbreaks and not individual infections. An outbreak consist of two or more linked cases of the same illness. Individual infections may be reported if the illness is formally notifiable, or if they cause mortality (e.g. primary septicaemia due to $V$. vulnificus). Scientific reviews of illness may be confined to individual foods or types of micro-organisms. These may contain information not available from the epidemiological data.

The fullest reviews of seafood-associated outbreaks are available for the United States and England \& Wales although some information is available for other countries. Most of these reviews were last undertaken for the 1990s and has not been systematically been assessed more recently. These reviews will be examined and compared here. Other data on the occurrence of illness related to vibrios will be separately examined in more depth.

Over the period 1992-1999, there were 1425 outbreaks in England and Wales associated with fish and shellfish and 181 of these (8\%) were due to seafood consumption (Gillespie et al., 2001). The seafood type and identified cause are shown in Table 11.4

This shows that the predominant illness associated with fish consumption was scombrotoxin and that associated with bivalve mollusc consumption was viral gastroenteritis. Bacterial infections associated with the consumption of both fish and crustacea in temperate developed countries appear to be those associated with foods in general and none that is specific to the origin and processing of the foods. This is not the case with bivalves, which, in Europe, are largely either sold as live in-shell animals (except for cockles which are sold as commercially heat-treated products) and which may, especially in the case of oysters, be consumed raw. This would suggest that the small numbers of bacterial outbreaks associated with fish and 
crustacea are due to post-harvest contamination, the live in-shell bivalves being naturally protected from this.

In the US, between 1993 and 1997, there were 2751 reported food-associated outbreaks and $47(1.7 \%)$ were identified as due to shellfish consumption and 140 (5.1\%) due to shellfish consumption (Huss, Ababouch \& Gram, 2004). The seafood types and identified causes are shown in Tables 11.5 (fish) and 11.6 (bivalve shellfish).

A worldwide review of foodborne disease was published in 1997 (Todd, 1997). This included some consideration of seafood-related disease. In France, from 1990 to 1992 inclusive, the 60 (8.4\%) of the 717 reported outbreaks were associated with the consumption of seafood: Salmonella (21 outbreaks); S. aureus (4); Other (35); no seafood-related outbreaks were attributed to $C$. perfringens. The same review showed that seafood was incriminated in $31.8 \%$ of outbreaks in the Republic of Korea and $21.7 \%$ of outbreaks in Japan.

Sumner and Ross (2002) reported that 32 seafood-related outbreaks involving 2158 people occurred in Australia in the period 1990-2000 and that 6 outbreaks involving 159 cases were due to bacterial pathogens.

A review of bivalve mollusc-associated disease in the US from 1984-1993 showed that, of the 2548 reported cases of illness, 546 were due to vibrios as were 95 of the 96 reported deaths (Wittman and Flick, 1995). The other bacterial causes were Salmonella (8 cases), Shigella (76 cases) and Campylobacter (12 cases). 
In 2006, there were 154 isolates of vibrios from laboratory confirmed illness by the CDC's FoodNet Surveillance network in 10 US States. . Of the 147 for which a species identification was given, 94 (64\%) were V. parahaemolyticus, and 18 (12\%) were V. vulnificus (CDC, 2007). It was noted that this represented the highest level of vibrio infection reported by the network since it started and that most cases were due to raw seafood, principally oysters.

Todd (1997) reported that the proportion of foodborne outbreaks due to Vibrio spp. in a number of countries were: Japan (47.3\%), Korea (37.6\%), Taiwan (55.3\%), Australia (3\%). No outbreaks caused by vibrios were reported from 16 European countries. While most of the reported vibrio-associated outbreaks were due to $V$. parahaemolyticus, a number of outbreaks due to $V$. cholerae $\mathrm{O} 1$ were also reported, including one in Japan related to imported Korean clams.

The National Institute of Infectious Diseases in Japan reported that there were 496 outbreaks of V. parahaemolyticus food poisoning during the period 1996-1998 (102 in 1996, 160 in 1997, and 234 in 1998). Two outbreaks involved more 500 cases each. One of these outbreaks was associated with boiled red queen crabs and serotype O3:K6 V. parahaemolyticus. The other large outbreak was associated with catered meals and multiple serotypes of $V$. parahaemolyticus; the nature of the meals was not stated.

Two large outbreaks of $V$. parahaemolyticus occurred in Chile in 2004 and 2005, affecting approximately 1500 people in 2004 and approximately 3600 people in 2005 (Fuenzalida, et al., 2006). The outbreaks were due to the O3:K6 pandemic clone which had been first seen in south-east Asia in 1996. Before 2004, V. parahaemolyticus infections had been rare in Chile. 
11.6 Conventional methods for the detection, enumeration and identification of bacterial pathogens

\subsubsection{Introduction}

Conventional methods for detection of foodborne pathogenic microorganisms are dependent on the growth of microorganisms, to the extent of being able either to form visible colonies in solid media, or to produce a detectable chemical change in liquid media. In seafood, as in other food, pathogenic bacteria are often present in relatively low numbers, outnumbered by spoilage microorganisms and possibly damaged by processing operations. Then the qualitative or quantitative detection is a complex procedure involving the different stages: resuscitation or pre-enrichment, enrichment and selective plating, followed by subsequent identification through morphological, biochemical and /or immunochemical tests.

Resuscitation may involve preliminary incubation in nonselective media or, alternatively the addiction of protective compound such as pyruvate or egg yolk to solid selective media. Enrichment is applied where pathogenic microorganisms are present only in small number, particularly if large numbers of spoilage microorganisms are present. Although in many cases enrichment media are used in conjunction with selective plating media, they may be used to enumerate specific bacteria or group of bacteria using the Most Probable Number (MPN) technique. In such cases it is necessary to incorporate the diagnostic reaction to distinguish the micro-organism being enumerate to other micro-organisms (i.e. "sulphide” reaction in media for clostridia). However such differentiation must be regarded as presumptive and confirmatory tests (biochemical and /or immunochemical tests) are required.

Within Europe, reference methods are specified for the detection and/or enumeration of bacteria for which legislative standards are defined (European Communities, 2005). It is 
assumed that the reference methods will be use for official control purposes. Alternative methods may be used for testing undertaken by food business operators if they are validated against the reference method. In particular, proprietary methods have to be certified by a third party in accordance with the protocol set out in EN/ISO standard 16140 or another internationally accepted similar protocol. The European Commission, via the European standardization organization, CEN, has commissioned the validation of a number of methods for which the available information was deemed to be insufficient. These approaches should help to ensure that the results obtained by different laboratories are equivalent.

Many methods traditionally used for pathogens in foods have been qualititative, using enrichment (non-selective and/or selective) followed by plating on a differential selective medium. A standard weight of $25 \mathrm{~g}$ of food has customarily been used in such tests. However, the different pathogens vary widely in their infectious dose and therefore results obtained using this approach do not relate to the risk posed by the pathogen/food combination. This drawback has been recognized for listeria in the EU microbiological criteria for foods where different standards are specified depending on whether the foods are able to support the growth of listeria and also whether they are intended to be eaten by particular at risk groups such as infants. This approach has not, however, been taken for all of the pathogens covered by the Regulation.

Classical methods are characterized by a good sensitivity, specificity and are able to determine only the viable cells, but they present some disadvantages. Firstly, they tend to be labour-intensive and time-consuming. Secondly, they do not always allow the detection, or more especially the enumeration, of relatively small numbers of bacterial cells of pathogenic species in the presence of large numbers of cells of non-pathogens. Thirdly, they do not necessarily allow the reliable detection of strains of potential pathogens that possess 
pathogenic principles, e.g. the ability to form toxins, especially in the presence of nonpathogenic forms of the same species. Therefore, many research efforts have been devoted to the development of rapid and sensitive alternative methods (Vaneechoutte and Van Eldere, 1997; Croci, et al., 2004; Panicker, et al., 2004). Application of DNA and RNA probes, immunochemical methods and detection of bioluminescence are some of the tools currently used (Hill, 1996; Meer and Park, 1995; Jaykus, 2003; Nelson, et al., 2007). In particular the Polymerase Chain Reaction (PCR) technique allows to improve detection and characterization of bacteria, using species-specific DNA regions and specific traits of pathogenicity, in addition to present several advantages over conventional methods with respect to detection limit, speed and potential for automation (Vaneechoutte and Van Eldere, 1997)

11.6.2 Conventional methods for specific pathogens

Conventional methods for the detection of some seafood associated pathogens, with particular attention to pathogenic vibrios, are reported.

\section{Salmonella spp}

The genus Salmonella, belonging to the Enterobacteriaceae family, includes Gram-negative bacteria which have both a respiratory and fermentative metabolism of carbohydrates. The cultural methods for the isolation and detection of salmonella in food are well established. Regulation (EC) No.2073/2005 for microbiological criteria in foodstuff reports that the salmonella must be absent in $25 \mathrm{~g}$ and the analysis must be performed on 5 sampling units by means of the EN/ISO 6579 reference method. This method currently involves nonselective pre-enrichment in buffered peptone water followed by selective enrichment in Rappaport 
Vassiliadis Soya Broth and Muller-Kauffmann tetrathionate/novobiocin broth followed by selective plating of these on xylose lysine deoxycholate agar (XLD) and one other selective agar of the laboratory's choice. Any suspect salmonella strains that are isolated are be confirmed by biochemical and serological test methods.

The ISO method has not been fully validated for $S$. Typhi and $S$. Paratyphi and so, if these species are of specific interest, it is presently advisable to subculture the buffered peptone water to selenite broth as an additional selective enrichment, followed by plating on Bismuth Sulphite agar.

\section{Clostridia}

The genus Clostridium, that currently contains more than 80 species diverse in terms of metabolic activity, nutritional requirements and DNA relatedness, comprises Gram-positive endospore-forming bacteria which are obligate anaerobes. Two species $\mathrm{Cl}$. botulinum and $\mathrm{Cl}$. perfringens are primarily involved in food poisoning but also Cl. baratii and Cl. butyricum have been involved in botulism cases. The EU microbiological criteria regulation does not contain any stipulations relating to clostridia. The method of CDC (Botulism in the United States, 1899-1996. Handbook for epidemiologists, clinicians and laboratory workers. (1998) CDC, Atlanta, GA, USA) is suggested with some modifications for the detection botulism neurotoxin producing clostridia. In particular for the detection of $\mathrm{Cl}$ butyricum type E spores and Cl.baratii Type F, the heat treatment of the sample should be carried out at $70^{\circ} \mathrm{C}$ and in the isolation of the toxic strains also the lipase negative colonies should be considered.

\section{Listeria}


The genus Listeria comprises Gram-positive, coccoid to rod-shaped, bacteria with a characteristic tumbling motility at room temperature. Between the species currently recognized only L. monocytogenes is consistently associated with human diseases and two other hemolytic species, L.ivanovii and $L$. seeligeri have been implicated in rare occasions. $L$. monocytogenes is a well-known cause of abortion, encephalitis and septicemia in man and animals. The microorganism can cause both invasive and non- invasive infections. $L$. monocytogenes is ubiquitous bacterium occurring in both terrestrial and aquatic habitat and has been isolated from fish and fishery products from different part of the world.

For foods, other than those that may be fed to infants and for special medical purposes, the EU microbiological criteria regulation specifies two different limits and associated reference methods. For foods that can support the growth of $L$. monocytogenes there is a requirement for absence in $25 \mathrm{~g}$ in 5 sampling units at the processing plan, with the reference method specified as EN/ISO 11290-1. For those same foods on the market, and for foods which do not support the growth of L monocytogenes, the limit is 100 colony forming units (cfu) per gram in 5 sampling units. The latter group of foods is deemed to include live bivalve molluscs. For these, the reference method is EN/ISO 11290-2.

The presence /absence method EN/ISO 11290-1 consists of an initial enrichment step in HalfFraser broth followed by a second enrichment in Fraser broth. Both broths are cultured on Agar Listeria according to Ottaviani and Agosti (ALOA) and a second medium of the laboratory's choice. The enumeration method EN/ISO 11290-2 consists of a plate count on ALOA following brief resuscitation in either buffered peptone water or Half-Fraser base. Confirmatory tests are carried out on presumptive colonies from both media. 
Staphylococcus aureus

The genus Staphylococcus contains a number of species which have been implicated as causative agents of disease in man and animals. Staphylococcus aureus is a major cause of food poisoning in man as well as of a range extraintestinal infections. Staphyloccocci are gram-positive rods. S. aureus isolates pathogenic for humans usually coagulate human and rabbit plasma (the coagulase test). Regulation (EC) No.2073/2005 for microbiological criteria in foodstuff states that for process hygiene of shelled and shucked products of cooked crustacea and mussels, the Staphylococcus aureus number must not exceed $1000 \mathrm{cfu} / \mathrm{g}$ in two of five sampling units and in the remaining must not exceed $1000 \mathrm{cfu} / \mathrm{g}$. The reference method for this is EN/ISO 6888-1 or 2. The first of these is a plate count on Baird-Parker (BP) agar and the second is a pour plate in BP-RPF (Rabbit plasma + bovin fibrinogen) Agar. Colonies on BP Agar require confirmation by the coagulase test while BP-RPF agar gives this confirmatory result in situ.

Vibrios

Bacteria of the genus Vibrio are ubiquitous in marine and estuarine aquatic ecosystems. Among more than 20 Vibrio species known to be associated with human disease, V. cholerae, $V$. parahaemolyticus and $V$. vulnificus are most important.

To date, the detection of pathogenic vibrios in seafood products is mostly performed by conventional cultural methods, including the new technical specifications ISO TS 28172 parts 1 and 2, followed by biochemical identification of the isolated strains. Part 1 is for $V$. parahaemolyticus and V. cholerae while part 2 is for other pathogenic vibrios. Both methods consist of an initial enrichment in Alkaline Salt Peptone Water (ASPW) followed by a second 
enrichment in the same broth, with the cultures from both being plated on Thiosulphate Citrate Bile Salt Sucrose Agar (TCBS) and one other agar. The difference between the two methods comes at the enrichment stages. For fresh products, both the first and second enrichments are undertaken at $41.5^{\circ} \mathrm{C}$ in the part 1 method while they are undertaken at $37^{\circ} \mathrm{C}$ in the part 2 method. For frozen products, the initial enrichment in part 1 is performed at $37^{\circ} \mathrm{C}$ in order to allow better recovery of damaged cells. Following isolation on the solid media, the presumptive colonies are identified biochemically (up to five colonies per plate). If they belong to a pathogenic species, they may then be submitted to a reference laboratory for the detection of pathogenic principles.

Cultural methods for pathogenic vibrios, including these ISO methods, suffer greatly from the drawabacks referred to earlier: the pathogenic vibrio species are often vastly outnumbered by nonpathogenic species and the strains of potentially pathogenic species possessing pathogenicity traits are usually vastly outnumbered by the non-pathogenic forms. This means that the probability of identifying a colony of a potential pathogen showing the pathogenicity traits is very low.

Enumeration of potentially pathogenic vibrios in seafoods is usually performed by one of two methods. The first is to perform plate counts directly on TCBS or one of the other selective isolation media. However, the recovery efficiency of these agars is usually only approximately $50 \%$ and may be even lower for stressed cells. The other method is to perform the initial enrichment in a 3x3 Most Probable Number format and then follow the rest of the isolation procedure for each initial broth. One problem with this is that the procedure results in a large number of presumptive colonies requiring confirmation. Another is that void MPN combinations are often obtained, with a lower than expected number of positives at the first dilution, presumably due to overgrowth by non-target bacteria. Some laboratories have used a 
semi-quantitative method with a single primary broth at each dilution, but the uncertainty associated with this method is very large.

For identification of isolated strains the miniaturized biochemical tests API 20E (commonly used for the identification of clinical isolates) and API 20NE, supplemented with $\mathrm{NaCl}$, are widely used (Croci et al., 2001; O'Hara et al., 2003; Truu et al., 1999). Despite different studies reporting the inadequacy of miniaturized tests for the identification of some isolates of the Vibrionaceae family (Colodner, et al., 2004; Dalsgaard, et al., 1996; Israil et al., 2003b; Martinez-Urtaza, et al., 2005), some authors pointed out the ability of the API 20NE system to provide a higher number of correct identifications than API 20E or other systems, particularly on the analysis of environmental isolates (Israil et al., 2003a; Toti et al., 1996). Another biochemical key for the identification of Vibrio spp. has been also proposed (Alsina and Blanch, 1994a; Alsina and Blanch, 1994b) and, after optimization of the conditions (temperature, time of incubation and media composition) by other authors (Ottaviani et al., 2003), good identifications have been obtained on a large number of reference and environmental Vibrio strains. Recently other systems have been proposed as Biolog GN system, based the bacteria identification on the exchange of electrons generated during respiration, leading subsequently to tetrazolium-based color changes, That seems to provide results on environmental strains in agreement with API 20NE (Truu et al., 1999). A comparison between some commercially available systems, Crystal E/NF panel, Rapid Neg ID, Vitek GNI+, ID-GNB cards and API 20E, showed that only Vitek cards and API20E presented an accuracy of $90 \%$ on $V$. parahaemolyticus identification. However a large proportion of misidentifications, with non-pathogens being identified as pathogens and vice versa, have been shown. A study for the evaluation of biochemical identification methods, API 20E and API 20NE and Alsina's by means of an intra and inter-laboratory test in order to determine the accuracy and concordance of each method.has been performed at the beginning 
of SEAFOODplus project. The Alsina’s scheme resulted the most efficient for Vibrio identification, but required a larger amount of work for the Laboratory (including the preparation of the culture media and their quality control). The API systems, despite the advantages brought by their quick and easy execution, showed a lower efficiency in the identification of $V$. parahaemolyticus. However the authors concluded that in order to avoid false positive results the confirmation of the results by means of a reliable molecular method it is necessary (Croci, et al., 2006)

11.7 Molecular methods for the detection, enumeration and identification of bacterial pathogens

Detection of pathogenic bacteria in seafood is essential to ensure safe products for consumers and sustainable fish and shellfish growing activities. Molecular diagnostic methods have evolved significantly in the last few years and they are established as useful and reliable to allow the rapid detection and identification of pathogens.

Molecular detection, identification and enumeration of Vibrio spp. are largely based on PCRamplification following purification of nucleic acids from the samples. Although less sensitive and more time consuming, DNA or oligonucleotide probe-based hybridisation methods have been proposed for Vibrio spp. in food.

In this chapter, the different methods commonly applied to pathogenic bacteria are discussed with particular emphasis to enteropathogenic vibrios - scope of the SEABAC project.

11.7.1 Detection and identification methods 
A number of PCR-based assays has been utilised to amplify Vibrio spp. from food, blood, fecal and environmental samples. While largely used for the detection of pathogens in the clinical diagnosis of microbial infections and also for the detection of these organisms in food and environmental samples, they were first developed to confirm the identification of isolated strains in place of biochemical tests.

PCR assays for identification

Different genes to detect and identify $V$. parahaemolyticus have been targeted. The use of gyrB gene, encoding the B subunit of DNA gyrase, for the detection of V. parahaemolyticus and closely related $V$. alginolyticus strains has been proposed by Venkateswaran, et al. (1998). However, Kim, et al. (1999) reported that the amplicon used to identify $V$. parahaemolyticus was also present in $V$. alginolyticus strains and they proposed the use of toxR gene, described as the regulatory gene of the cholera toxin operon and of other virulence determinants of $V$. cholerae and involved in the regulation of many genes of Vibrio species and in particular of $V$. parahaemolyticus (Lin, et al., 1993). Two toxR gene-targeted PCR protocols, established for $V$. parahaemolyticus specific detection, did not generate nonspecific amplicons by some strains of $V$. vulnificus and $V$. alginolyticus (Kim et al. 1999). Bej, et al. (1999) suggested that PCR amplification of the th gene, which encodes a thermolabile hemolysin (TLH), was V parahaemolyticus specific but Robert-Pillot, et al., (2002) demonstrated that $t l$ gene was not useful to differentiate $V$. parahaemolyticus and $V$. alginolyticus. Other authors proposed the amplification of the R72H sequence, a highly conserved fragment in $V$. parahaemolyticus strains located after an rRNA operon, for species specific detection, although its function is unknown (Lee, et al., 1995; Wu and Lee, 1998). A comparison of five PCR methods (toxR, gyrB, pR72H and two different protocols for $t$ lh 
gene) available for the identification of $V$. parahaemolyticus was performed within the SEAFOODplus project. The aim was to define the most effective to use as support or substitute to the biochemical testing in the laboratories involved in the control of fishery products. The results indicated that the PCR targeting the toxR gene (Kim, et al., 1999) was the most reliable with an inclusivity and an exclusivity of $100 \%$ and suggest that the tox $R$ gene could be a valid support for species confirmation, to use in association or as a substitute to biochemical testing of isolates (Croci, et al., 2007).

PCR assays for detection

Several conventional PCR assays have been used successfully for the detection of $V$. parahaemolyticus by employing species-specific PCR primers designed on the nucleotide sequences of several targeted genes. Amongst others, the th gene, the gyrB gene, the toxR gene, as well as the pR72H cloned fragment have been targeted as markers for all $V$. parahaemolyticus strains (Taniguchi, et al., 1986; Venkateswaran, et al., 1998; Kim, et al., 1999; Lee, et al., 1995). The genes encoding major virulence determinants have been used to characterise and distinguish potentially enteropathogenic from all $V$. parahaemolyticus strains. Tada, et al. (1992) reported primers for the detection of $t d h$ and trh genes encoding for the production of two thermostable haemolysins associated with disease, Thermostable Direct Haemolysin (TDH) and TDH-related Haemolysin (TRH), respectively. An open reading frame (ORF8) in a lysogenic filamentous phage was selected for specific detection of V. parahaemolyticus strains belonging to the pandemic clone, O3:K6 (Nasu, et al., 2000).

Until recently, the pR72H, the toxR, the TDH and the TRH PCR assays have been the most widely used in epidemiological investigations, surveillance and shellfish purification studies 
in Asia, America and Europe (Cordova, et al., 2002; Croci, et al., 2002; Hervio-Heath, et al., 2002; Alam, et al., 2003; Martinez-Urtaza, et al., 2004, Robert-Pillot, et al., 2004).

Multiplex PCR assays for simultaneous detection of total and enterotoxigenic $V$. parahaemolyticus (Bej, et al., 1999) or of V. parahaemolyticus and other Vibrio spp. (Tarr, et al., 2006) or marine bacteria (Gonzales, et al., 2004) were developed. They were tested for the identification of isolated $V$. parahaemolyticus strains or for the detection of these bacteria in seeded oyster tissue homogenates but they were rarely used for field investigations because they lack sensitivity. Lee, et al. (2003) reported that the combination of a multiplex PCR with a colorimetric microwell plate sandwich hybridisation assay improved the sensitivity and permitted validation of the amplified DNA.

Reverse transcription-PCR (RT-PCR), which targets short-lived messenger RNA molecules, has become an increasingly used molecular method for assessing the viability of bacteria, culturable (VC) or nonculturable (VBNC). The latter state is a survival strategy adopted by bacteria who are exposed to hostile environmental and are no longer capable of growing on conventional bacteriological media but conserve pathogenic factors and/or genes. Vibrio parahaemolyticus RT PCR, targeting transcripts of the rpoS and the $t d h 2$ genes, has been described to detect cDNA from VBNC cells for extended period of time (Coutard, et al., 2005).

DNA microarrays and biosensors 
Next generation assays under development include biosensors and DNA microarrays that potentially have the capability for near real-time and on-line monitoring for multiple pathogens in foods or environmental samples.

Several studies have demonstrated the applicability of DNA arrays to environmental microbial detection (Gushin, et al., 1997). Combined or not with multiplex PCR assay, these oligonucleotide arrays have been employed to detect and discriminate $V$. parahaemolyticus from other human pathogenic vibrios or other foodborne pathogenic bacteria (Panicker, et al., 2004; Vora, et al., 2005; Jin, et al., 2006; Eom, et al., 2006).

\subsubsection{Enumeration methods}

Colony hybridization

In recent years, the use of DNA probes to identify colonies growing on non-selective or semiselective agar media have been proposed for detection and enumeration of $V$. parahaemolyticus and V. vulnificus. Alkaline phosphatase (AP)-labeled probes (available commercially) or digoxigenin (dig)-labeled amplicon probes can be used to identify the presence of $V$. parahaemolyticus and strains harbouring the $t d h$ gene, and detecting $V$. vulnificus. Although it is generally considered that PCR methods are more sensitive and less time consuming than either DNA or oligonucleotide probe-based hybridisation methods, a number have been proposed for detection, biotyping and confirmation of the identification of Vibrio spp. in food. McCarthy et al. (1999) evaluated an alkaline phosphatase- and a digoxigenin- (DIG) labelled tlh probe for V. parahaemolyticus specificity. An AP-labelled $t d h$ probe and two DIG-labeled $t d h$ and $t r h$ probes for the numeration of enterotoxigenic $V$. parahaemolyticus were also described. These methods have been widely used for the 
enumeration of both $V$. parahaemolyticus and $V$. vulnificus in regulatory laboratories and surveillance studies across the United States (De Paola et al., 2000; Cook et al., 2002; FDA, 2004) but in a limited number of study in Europe. Their applicability for the detection of V.vulnificus and V.parahaemolyticus has been verified within the SEAFOODplus project using a large number of strains of different origins (ATCC, clinical, environmental). The method for the V.vulnificus detection using $v v h$ probe provided good performance. On the contrary the method for the V.parahaemolyticus detection using th probe provided some false negative results for strains isolated from Adriatic Sea, Africa, imported fisheries. Then the development of alternative probe using tox $R$ gene has been planned. By means of the alignment of the sequences of all strains available and on the basis of Blast (NCBI) a probe was designed and provided good results, performing well in the range $80-90^{\circ} \mathrm{C}$. The experimental conditions (hybridisation temperature, buffer composition, etc.) have been optimised. Experiments performed under repeatability conditions using reference strains and recently collected environmental isolates have yielded good results. Specificity has been confirmed against a large panel of non-parahaemolyticus Vibrio spp. and non-Vibrio spp.

\section{MPN-PCR}

DNA hybridisation and PCR methods combined with an enrichment in an MPN format have been used extensively to enumerate bacterial pathogens. A PCR and a multiplex PCR method, targeting the pR72H fragment, the toxR gene and the $t h$, $t d h$ and trh genes, respectively, were combined with a MPN technique to enumerate the total and enterpathogenic $V$. parahaemolyticus in mussels, seawater and marine organic material (Croci, et al., 2002; Alam, et al., 2002). This combination proved to be more sensitive and specific than the conventional culture-based MPN method. This was used in a recent study to 
evaluate the levels of total and tdh positive $V$. parahaemolyticus in retailed seafood in Japan (Miwa, et al., 2006).

\section{Real-Time PCR}

While conventional PCR-based methods are specific and sensitive and provide good alternative assays to conventional culture for the detection of V. cholerae, V. vulnificus and total and/or enteropathogenic $V$. parahaemolyticus in seafood, they are not useful for enumeration. Real-time PCR combines the specificity of conventional PCR with the quantitative measurement of fluorescence for determining the presence of specific types of nucleic acids in environmental samples. These offer the potential for a more rapid and quantitative analysis for the detection, and enumeration, of pathogenic bacteria.

SYBR Green or the use of TAQMAN probes are the more frequently selected for the numeration of Vibrio spp. Many authors reported the application of real-time PCR for quantitative detection of Vibrio spp. in seafood and seawater water (Panicker, et al., 2004b; Blackstone, et al., 2007, Takahashi, et al., 2005, Ward and Bej, 2006). However, detection of these bacteria was possible only after enrichment of tissue homogenates or water. To date, only one study refers to detection of $V$. parahaemolyticus directly from naturally contaminated seafood (Cai, et al., 2006), the number of cells varying from $4.3 \mathrm{x} 10^{3}$ to $4.7 \mathrm{x}$ $10^{5}$ per ml. These results indicate that PCR amplification can be inhibited by components from the different food matrices and that these methods still lack sensitivity for direct testing. It is for this reason that this methodology has been selected for optimisation and standardisation within the scope of the SEAFOODPLUS programme particularly for the estimation and detection of total and enteropathogenic V. parahaemolyticus in shellfish. Research performed with the SEAFOODPLUS (SEABAC) project have enabled progress in 
sample preparation (concentration of microorganisms) and nucleic acid extraction and the optimisation of real-time PCR for the detection of the bacteria in shellfish. The transfer of the methodology for inter-laboratory trials will in the future enable elaboration of a standard realtime PCR method for V. parahaemolyticus.

\subsubsection{Conclusion}

A drawback to these methods: a positive result in PCR or real-time PCR, for example with a probe or primers specific for a toxin gene, only indicates that the bacteria carrying this gene are present in the sample and thus, have the potential to be toxigenic. However, it does not indicate if the gene is expressed or the toxin produced.

Furthermore, if more rapid than culture, these methods still lack sufficient sensitivity and specificity for direct testing. Indeed with few exceptions, almost all assays used to detect specific pathogens in foods require some growth in an enrichment medium before analysis.

However, considering the increasing importance of Vibrio spp., the molecular approach is a reliable alternative procedure for routine microbial screening and monitoring of clinical, food and environment samples and offers interesting perspectives for epidemiological, phylogenetic and environmental studies.

11.8 Molecular approaches to microbial typing

\subsubsection{Introduction}

Molecular typing methods involve the examination of chromosomal or extra-chromosomal DNA or RNA. Based on the technical approach, four different categories are usually recognized: plasmid analysis; hybridisation; nucleic acid amplification-based methods using 
PCR with or without sequencing and macrorestriction pattern (MRP) analysis by the use of infrequent cutting enzymes and pulsed-field gel electrophoresis (PFGE). To varying extents intra-species characterisation of pathogenic seafood borne bacteria has been achieved using the majority of these approaches with various degrees of discriminatory success.

The basis for all molecular typing methods is that all pathogenic agents within an infectious chain are clonally related. Thus successful typing systems effectively determine markers that can optimise discrimination between epidemiological related and unrelated isolates of the pathogens of interest (Streulens, 1998). In food microbiology genotyping methods are most commonly employed in outbreak investigations. However, they have also been used in confirmation or delineation of the patterns of transmission, testing hypotheses on the origin and vehicles of transmission, and in the monitoring of reservoirs of clinically significant bacterial strains. Typing has also in some cases contributed to epidemiological surveillance and evaluation of control measures, by assessment of the temporal prevalence and distribution of epidemic clones.

In this chapter, typing strategies commonly applied to seafood borne bacteria are discussed in brief with more extensive consideration given to the application of PFGE and RAPD techniques to Vibrio spp. within the context of the SEAFOODplus research programme. 11.8.2 Plasmid analysis

Plasmids are autonomously replicating extrachromosomal DNA found within bacteria. Frequently related strains contain the same number of plasmids with the same molecular weight and similar phenotypes. There are two major applications- typing of a specific plasmid profile and plasmid fingerprinting. Plasmid profiling is based upon the number and 
molecular weight of plasmids whereas, in plasmid fingerprinting, plasmids are digested with restriction enzymes before analysis. Both approaches have been used in a number of studies to sub-type a range of bacterial pathogens isolated from seafood or seafood products (Kumao, et al., 2002, Teophilo, et al., 2002, Chen, et al., 2003, Martinez-Urtaza, et al., 2004). Whilst plasmid analysis has been shown to be useful in the characterisation of specific bacterial strains e.g. exotoxin producing E. coli from fish and crustacaea (Teophilo, et al., 2002), many pathogens can spontaneously acquire or lose plasmids and this limits there use in epidemiological investigations.

\subsubsection{Hybridisation approaches}

\section{Ribotyping}

The most commonly utilised hybridisation approach is known as ribotyping. Ribotyping utilizes variations in the ribosomal genes and their adjacent sequences. These genes are usually highly conserved and vary in number and position. Chromosomal DNA is isolated, restricted and the resulting DNA fragments carrying the rRNA genes are separated by electrophoreisis. Detection is via hybridisation with labelled E. coli 16S, 23S or 5S probes (Grimont and Grimont, 1991). Over the last decade automated ribotyping systems have been introduced (Bruce, 1996). Automation has a number of benefits including increased standardisation, speed, reproducibility and repeatability and a decrease in non-typeable isolates (Suihko, et al., 2002). Ribotying has been used extensively in sub-typing of pathogenic bacteria derived from seafoods. In one notable study, Høi, et al. (1997) characterised Danish and U.S. isolates of $V$. vulnificus using ribotyping and RAPD PCR. Ribotyping enabled the identification of the first reported isolation of $V$. vulnificus biotype 2 . 
The authors concluded that ribotyping was be useful for biotyping whereas RAPD PCR was unable to correlate isolates with sources or to differentiate biotypes. In general, it has been reported that ribotyping produces fewer patterns and clusters requiring less complex interpretation than many other sub-typing methods, and that ribotypes show a good relationship between geographical distribution and genotype (Tamplin, et al., 1996)

11.8.4 Nucleic acid amplification-based typing methods by using PCR

A number of PCR based typing approaches have been applied to characterisation of seafood borne bacteria. Most commonly these have included repetitive element PCR (Rep PCR) and randomly amplified polymorphic DNA (RAPD).

Repetitive element PCR (Rep PCR)

Rep (PCR) uses PCR amplification of the DNA between adjacent repetitive extragenic elements to obtain strain specific DNA fingerprints (Versalovic, et al., 1991). Three main rep-PCR methods (ERIC-PCR, REP-PCR, and BOX-PCR) are usable for bacterial typing. Each method uses one or several oligonucleotides homologous to a defined sequence that is present in multiple copies on the bacterial chromosome.

In a study on the relatedness of outbreak related strains of $V$. parahaemolyicus Marshall, et al. (1999) concluded that ERIC PCR exhibited good discrimination and could be used to evaluate genetic and epidemiological relationships. Wong and Lin (2001) reported on the design and evaluation three rapid PCR typing methods, including ERIC PCR, in addition to ribosomal gene spacer sequence (RS), and repetitive extragenic palindromic sequence. In this 
study, in which the efficacy of each method was compared to PFGE patterns, typing patterns and clustering analysis differentiated between 15 and 27 patterns amongst $40 \mathrm{~V}$. parahaemolyticus strains presenting a wide range of PFGE profiles. High discrimination indices were recorded for all methods however, assay reproducibility was identified as a potential drawback when using ERIC-PCR. Khan, et al. (2002) used ERIC PCR followed by conventional PCR amplification of a unique 327 bp fragment in newly emerged pathogenic strains of O3:K6 in a Texan outbreak However, only a limited number isolates were tested (18) in this study, and the reproducibility and reliability of this approach has been questioned by others (Myers, et al., 2003).

Random amplified polymorphic DNA (RAPD)

Randomly amplified polymorphic DNA (RAPD) is a PCR-based method utilising short random primers to rapidly detect genomic polymorphisms under low-stringency conditions. RAPD analysis has been is widely used for differentiating between seafood-borne bacterial isolates and relies upon small quantities of genomic DNA, which can be of particular benefit when typing slow growing or fastidious bacteria.

RAPD PCR has frequently been used to sub-type isolates of $V$. vulnificus as it been identified that other methods such as PFGE are not suitable due to the high level of intra-specific diversity of isolates from clinical and environmental sources (Buchreiser, et al., 1995; Tamplin, et al., 1996) and the sensitive discriminatory capability of PFGE. Warner and Oliver (1998) developed a RAPD PCR protocol for the detection V. vulnificus. The authors reported clear differentiation between clinical and environmental isolates and unique banding patterns indicating that $V$. vulnificus comprised a highly heterogeneous group. In a more 
recent study Lin, et al. (2003) used RAPD PCR to analyze the temporal and spatial intraspecific diversity of $V$. vulnificus strains isolated from Galveston Bay water and oysters. Cluster analysis of RAPD PCR profiles confirmed a high level of intra-specific diversity among the strains with no correlation between the variation and sampling site or source of isolation. However, a major shift in population structure was observed with rising water temperatures. The authors concluded that RAPD PCR enabled sensitive monitoring of temperature sensitive genetic population changes.

Ripabelli, et al. (2003) utilised RAPD PCR in molecular characterisation studies on $V$. vulnificus isolated from Mussels in Italy. The results demonstrated extreme intra-specific variability of $V$. vulnificus. Arias, et al. (1998) analysed RAPD PCR profiles of $V$. vulnificus (clinical, environmental, and diseased-eel isolates from different geographic origins, plus seawater and shellfish isolates from the western Mediterranean coast, including reference strains) comparing the results to ribotyping. Both ribotyping and RAPD PCR indicated a high level of homogeneity of diseased-eel isolates, in contrast to the genetic heterogeneity of Mediterranean isolates. It has been suggested that RAPD PCR is superior for rapid typing in the routine analysis (Ripebelli, et al., 2003).

Research carried out within SEAFOODplus has described the first molecular characterisation of Vibrio sp.p isolated in the EU using RAPD. These results have demonstrated that RAPD is a relatively quick, reproducible and easy method for subtyping bacterial organisms. RAPD has been shown to differentiate between different Vibrio species isolated from the environment as well as enabling identification of intra-species variation in $V$. parahaemolyticus (Figure 11.1). 
Macrorestriction pattern analysis and pulsed field gel electrophoresis

Pulsed field gel electrophoresis (PFGE) is a technique that enables analysis of entire chromosomal DNA previously digested with a restriction endonuclease to yield large DNA fragments (Towner and Cockayne, 1993). Over recent years PFGE has emerged as the "gold standard" in typing methodology (Maslow and Muligan, 1996; Streulens, 1998). It is the current method of choice for typing nosocomial and community acquired pathogens (Tenover, et al., 1997). In comparison with other typing methods it shows a high level of discriminatory ability and most systematic studies of typing performance have included comparisons with PFGE. PFGE has been reported to have the most discriminatory power with respect to the characterisation many seafood borne bacterial pathogens including $V$. cholerae (Cameron, et al., 1994; Dalsgaard, et al., 1996; Kam, et al., 2003), L. monocytogenes (Johansson, et al., 1999), Clostridium spp. (Hyytia, et al., 1999), and Salmonella spp. (Martinez-Urtaza, et al., 2004).

In South East Asia and North America where amongst seafood-borne bacterial pathogens Vibrio spp. are considered to be predominant, PFGE has been used extensively (Bag, et al., 1999; Chowdury, et al., 2000; Lu, et al., 2001). It has been reported that PFGE has provided adequate discrimination and is widely considered as a superior $c f$ alternate typing procedures. In a Tawainese study on the heterogeneity of $V$. parahaemolyticus strains recovered from seafood and the environment, Wong et al. (1999) demonstrated a high level of genetic diversity in V. parahaemolyticus isolates. Likewise in Europe, Martinez-Urtaza, et al. (2004) demonstrated a considerable degree of heterogeneity amongst isolates from Spanish coastal waters and seafood. Extensive heterogeneity has been confirmed amongst non TDH/nonTRH strains collected from European fish and shellfish as part of the SEAFOODplus 
programme (Figure 11.2). PFGE has also been used in the analysis of clinical isolates from Spain and strains from Galician oysters. PFGE clearly distinguished Spanish clinical isolates from the Asian and North American pandemic clones. Recently research carried out within SEAFOODplus has identified clonal relationships between Spanish clinical strains and strains originating from a patients with enteritis in the UK (Figure 11.3).

One major drawback of PFGE is the lack of standardisation of PFGE protocols and resultant difficulties in inter-study comparison. Most authors have recognised that to promote effective bacterial and epidemiological tracking and disease control, internationally standardised typing procedures and an international PFGE fingerprint database should be established. It is for these reasons that this methodology has been selected for development and standardisation within the scope of the SEAFOODPLUS programme particularly for application to Vibrio spp. Research forming part of the SEAFOODPLUS programme has enabled the elaboration of a standard PFGE method for $V$. parahaemolyticus using two restriction enzymes (NotI and SfiI). In inter-laboratory comparisons this method has demonstrated excellent resolution and reproducibility. Adoption of standardised PFGE protocols will in the future enable data generated in single and multi-laboratory studies to be reliably compared.

\subsection{Future trends}

\subsubsection{Emerging bacterial risks}

In terms of bacteriological food safety emerging disease risks can be described as the first linkage between a particular bacteria or bacterial strain and disease, those that cause a sudden 
increase in frequency or severity of illness particularly in non-endemic regions, or when a recognised pathogen reappears as a significant cause of disease in the community. Numerous and diverse bacterial species have been isolated from seafood in the absence of definitive aetiologic connection to fish or shellfish related outbreaks. Although many such organisms pose significant health risks for immune-compromised individuals or other susceptible groups, several, such as Pseudomonas spp., Aeromonas spp., and Pleisomonas spp. commonly form part of the natural flora of seafood. Whereas many of these organisms have usually been considered harmless or related to bacteria spoilage, the emerging pathogen Stenotrophomonas maltophilia, formerly known as Pseudomonas maltophilia, has received attention in recent years due its putative role in a number of clinical syndromes such as cystic fibrosis, bacteremia, endocarditis, skin and soft tissue infection, ocular infection, and urinary infection (Begoña Ben-Gigirey, et al., 2000, 2002). Over the last decade DNA probe techniques have become available to enable isolation and differentiation of S. maltophilia from commensal non-pathogenic species in high value commercial seafood products such as albacore tuna. Increasingly, application of molecular methods in food microbiology will make possible the detection, identification and differentiation of emerging bacterial risks associated with seafoods.

Although not usually related to faecal contamination of water, a number of studies have indicated an inverse association between the concentration of bacteria in the marine environment and faecal indicator levels (Kaper, et al., 1979; Tamplin, et al., 1982). Bacterial counts tend to be highest in warm summer months, particularly when water temperatures exceed $15-20^{\circ} \mathrm{C}$ (Baross and Liston, 1970) and this has led to a concern that a rise global seawater temperatures may result in increased consumer risk from seafood associated bacterial pathogens. International trade in wild caught seafood and an increase in aquaculture 
seafood products has facilitated the introduction of new and existing pathogens into novel geographic areas, as well as seafood and human communities. For example, Salmonella Agona, which has been increasingly responsible for outbreaks of salmonellosis in recent years in Europe, was first introduced with imported Peruvian fish meal and has subsequently been reported in many other food products, including aquaculture seafood (Flemming, et al 2006). Thus the international trade in seafood and fisheries products can signify an increased risk of exposure to geographically exotic pathogens. Similiarly, trade in aquaculture commodities from world regions where licensed or illegal antimicrobial prophylaxis is practiced can encourage the spread of antibiotic resistance within and often between bacterial species.

Finally, it is worthy of note that of the four bacteria identified in the United States as of major concern in food-borne disease namely E. coli O157:H7, Salmonella enteriditis, Listeria monocytogenes and Campylobacter jejeuni only S. enteriditis was an established food-borne disease agents 20 years ago (FAO, 2005), highlighting the relatively rapid appearance of bacteria food borne illness.

\subsubsection{Application of new methods}

Over the last 20 years numerous new non-classical methods in food microbiology have become available. Many of these have utilised techniques in molecular biology for the detection of particular bacterial species, specific pathogenicity genes or enterotoxins using PCR amplification and gene probes. Whilst there is currently no universal method that permits identification of all pathogenic bacteria a number of bacteria associated with fish and fisheries products have been successfully detected including L. monocytogenes; 
Campylobacter coli, C. jejuni, Campylobacter spp.; Clostridium botulinum, enterotoxigenic strains of E. coli, Vibrio spp., Salmonella spp. and Shigella flexineri (FAO, 2005). The advent of real-time quantitative PCR has signalled a move towards the development of methods for the direct quantitation of a number of target organisms in seafood matrices (Cai, et al 2005; Campbell and Wright, 2003; Takahashi, et al.,2005). However, to date most studies utilising this technology have recommended the use of enrichment culture prior to PCR amplification to concentrate bacterial cells and to eliminate the presence of inhibitors. Thus so far most published methods enable presence/absence determination but not enumeration of pathogens from the seafood matrix.

At present in within the EU no molecular based method is included in the list of analytical reference methods stipulated for use in official control testing of fish or fisheries products. The unsuitability of some existing cultural methods for seafood borne pathogens has been acknowledged previously (Feng, 1998) and it is noted in the EU Microbiological criteria for foodstuffs that there is a need for development of reliable methods for certain microbial hazards e.g. V. parahaemolyticus (Anon, 2005). Thus it is probable that following appropriate standardisation and validation molecular techniques for detection and/or enumeration bacterial pathogens will be incorporated into the European legislative framework. Currently through the European Committee for Standardisation (CEN) several molecular standard methods are being elaborated for use in food microbiology e.g. Clostidium botulinum neurotoxins by PCR, Yersinia enterocolitica by PCR and $V$. parahaemolyticus by nucleic acid hybridisation. The latter methodology for enumeration of potentially pathogenic $V$. parahaemolyticus in seafood having been developed during work carried out within the SEAFOODplus work programme. 


\subsubsection{Emerging treatment technologies}

For many years food scientists have sought alternative procedures that can preserve shelf life and reduce public health risks without compromising the taste and texture of products of highly perishable fish and fisheries products (West, 1989). Certain seafoods such as some species of crab, smoked fish, caviar and some imitation crab based surimi products have been traditionally pasteurised to reduce risks associated with Clostridium botulinum (type E and nonproteolytic B and F) Listeria monocytogenes and Vibrio vulnificus. In several countries guidelines for specific foodstuffs or reductions in target bacterial species have been adopted as part of HACCP procedures (ECFF, 1999; Gould, 1999; FDA, 2006). However, pasteurization involves a mild or moderate heat treatment and is therefore not appropriate for a number of fresh seafood or fishery products usually intended for consumption with no further processing. Additionally, it has been suggested that pasteurisation followed by chilling does not remove all public health risks (Pace, et al., 1988). And, that it may even facilitate the emergence in importance of members of the genera Bacillus and Listeria, that can survive pasteurisation and subsequently proliferate under refrigeration conditions (West, 1989).

A number of workers have reported that fish and seafood can be effectively decontaminated through irradiation, increasingly referred to a “cold pasteurisation”. Relatively low doses (1.0-2.0 kGy) have been shown to eliminate $V$. parahaemolyticus and $V$. vulnificus from a range of matrices (Matches and Liston, 1971; Molins, et al., 2001) without affecting the quality of fresh raw products such as live oyster and clams (Molins, et al., 2001). In the EU the use of irradiation to prolong shelf life and prevent food-borne diseases by reducing the number of viable micro-organisms in meat, poultry and seafood is foreseen under EC 
Directive 1999/2/EC (Anon, 1999). In 2005, irradiation facilities were approved in 10 member states and whereas a number of countries listed fish and fisheries products amongst the irradiated products (Anon, 2007) in practice, the use of this technique is limited in Europe compared with elsewhere.

More recently, high pressure (HP) processing has been investigated as an alternative method for food preservation that allows microbial inactivation whilst maintaining sensory and nutritional properties (Murchie, et al., 2005). The use of HP as a means of elimination of pathogenic bacteria associated with shellfish (oysters) has become of increasingly interest in recent years, particularly in the United States. This is largely due to the susceptibility of human pathogenic Vibrio spp. to relatively low HP treatments (circa 300MPa) (Voisin, 2001, 2002; Calik, et al., 2002). In addition, HP treatment has been reported to enhance the appearance of oysters compared with untreated products (Johnston, et al., 2003) and to cause detachment of the abductor muscle assisting in opening of the shell (He, et al., 2002). The advantages of HP over alternative processing methods has been demonstrated for other seafood products especially in Japan where it is used increasingly in the production of surimi and kamaboko (Ashie, et al., 1996). Despite the reported advantages of HP for the decontamination of fresh raw fish and fisheries products to date its use outside of the US and Japan are strictly limited.

\subsection{General discussion (ron)}

The proportion of outbreaks due to seafood varies markedly around the world, from around $10 \%$ to $30 \%$ of all foodborne outbreaks, and appears to be highest in south-east Asia although little information is available for Africa. The differences are undoubtedly related to variations 
in the proportion that seafood makes up of the diet; the nature in which seafood is usually eaten (i.e. whether a significant proportion is raw or uncooked); the local ambient temperature; local level public health. The proportion will also depend on whether vibrios are a significant cause of illness in a country although this is in itself related to a number of the other factors, as well as the occurrence of pathogenic species and forms in the environment. International travel and trade is also an important factor - a significant proportion of vibrio infections in Europe are due to persons infected abroad and returning during the incubation period or while still ill. Global change may lead to an increase in some types of seafood-associated illness. However, for some high-risk seafoods, such as oysters, new processing technologies may offer the potential for providing a safer product, as long as the result is acceptable to the consumers, particularly those that are used to eating raw products.

Conventional methods of detection, enumeration, identification and characterisation have been successfully used for some bacterial pathogens in seafoods but less successfully for others, such as vibrios, where they are unable to adequately distinguish pathogenic forms from non-pathogens. Better methods may provide additional information necessary for undertaking quanitative risk assessments for most pathogens. Newer molecular methods have the potential to overcome some of the drawbacks and thus contribute to seafood safety. In this respect, the molecular methods that have been investigated within the SEAFOODplus project are contributing to the establishment of better standard methods within the aegis of the International Standardisation Organisation.

11.11 Sources of further information and advice 
The following websites provide information relating to the microbiological safety of seafood.

Community Reference Laboratory for monitoring bacteriological and viral contamination of bivalve molluscs: http://crlcefas.org

European Commission - Food Safety: http://ec.europa.eu/food/index_en.htm

FAO Fisheries and Aquaculture Department: http://www.fao.org/fi/

FAO Agriculture and Consumer Protection Department: http://www.fao.org/ag/agn/

UC Davis Seafood Network Information Centre: http://seafood.ucdavis.edu/

WHO Food Safety: http://www.who.int/foodsafety/en/

National Food Safety/Standards Agencies will provide information specific to individual countries.

\subsection{References}

Alam, M.J., Tomochika, K., Miyoshi, S. and Shinoda, S. (2002), Environmental investigation of potentially pathogenic Vibrio parahaemolyticus in the Seto-Inland Sea, Japan, FEMS Microbiol Lett, 208, 83-87.

Alsina, M. and Blanch, A. R. (1994a), Improvement and update of a set of keys for biochemical identification of environmental Vibrio species. J Appl Bacteriol, 77, 719-721. 
Alsina, M. and Blanch, A. R. (1994b), A set of keys for biochemical identification of environmental Vibrio species, J Appl Bacteriol, 76, 79-85.

Anon (1999), Directive 1999/2/EC of the European Parliament and of the Council of 22 February 1999 on the approximation of the laws of the Member States concerning foods and food ingredients treated with ionising radiation.

Anon (2007), Report for the Commission on Food Irradiation for the year 2005. Official Journal of the European Union 2.6.2007.

Arias CR, Aznar R, Pujalte MJ, and Garay E. (1998), A comparison of strategies for the detection and recovery of $V$. vulnificus from marine samples of the western Mediterranean coast, Syst Appl Microbiol, 21, 128-134.

Ashie I. N. A., Simpson B. K. and Ramaswamy H. S. (1996), Spoilage and shell life extension of fresh fish and shellfish, Crit Rev Food Sci, 36, 87-121.

Bag P K, Nandi S, Bhadra R, Ramamurthy T, Bhattacharya S K, Nishibuchi M, Hamabata T, Yamasaki S, Takeda T, and Nair G B. (1999), Clonal diversity among recently emerged strains of V. parahaemolyticus 03:K6 associated with pandemic spread, J Clin Microbiol, 37, 2354-2357.

Baross J and Liston J (1970), Occurrence of Vibrio parahaemolyticus and related hemolytic vibrios in marine environments of Washington State. Appl Microbiol, 20 (2), 179-186. 
Ben-Gigirey B, Vieites Baptista de Sousa J M, Villa GT and Barros-Velazquez J (2000), Characterization of biogenic amine-producing Stenotrophomonas maltophilia strains isolated from white muscle of fresh and frozen albacore tuna, Int J Food Microbiol, 57 (1-2), 19-31.

Ben-Gigirey B, Vieites J M, Kim S H, Tomás H A, Villa G and Barros-Velázquez J (2002), Specific detection of Stenotrophomonas maltophilia strains in albacore tuna (Thunnus alalunga) by reverse dot-blot hybridisation, Food Control, 13 (4-5), 293-299.

Bej, A K, Patterson D P, Brasher C W, Vickery M C, Jones D D and Kaysner C A (1999), Detection of total and hemolysin-producing Vibrio parahaemolyticus in shellfish using multiplex PCR amplification of tl, tdh and trh. J Microbiol Methods, 36, 215-225.

Blackstone, G M, Nordstrom J L, Bowen M, Meyer R F, Imbro P and Depaola A (2007), Use of real-time PCR assay for the detection of the ctxA gene of Vibrio cholerae in an environmental survey of Mobile Bay, J. Microbiol Methods, 68 (2), 254-259.

Bruce J (1996), Automated system rapidly identifies and characterizes microorganisms in food, Food Technol, 50, 77-81.

Buchrieser C, Gangar V V, Murphree R L, Tamplin M L, and Kaspar C W (1995), Multiple V. vulnificus strains in oysters as demonstrated by clamped homogenous electric field gel electrophoresis, Appl Environ Microbiol, 61, 1163-1168. 
Cai T, Jiang L, Yang C, and Huang K (2006), Application of real-time PCR for quantitative detection of Vibrio parahaemolyticus from seafood in eastern China, FEMS Immunol Med Microbiol, 46, 180-186.

Calik H, Morrissey M T, Reno P W and An H (2002), Effect of high pressure processing on Vibrio parahaemolyticus strains in pure culture and Pacific oysters, J Food Sci, 67, 15071510.

Cameron DN, Khambaty FM, Wachsmuth K, Tauxe RV, and Barrett TJ. 1994. Molecular characterisation of V. cholerae O1 strains by Pulse Field Gel Electrophoresis. Journal of Clinical Microbiology, 32:1685-1690.

Campbell M S and Wright A C (2003), Real-time PCR analysis of Vibrio vulnificus from oysters, Appl Environ Microbiol, 69 (12), 7137-7144.

CDC 2007. Preliminary FoodNet Data on the Incidence of Infection with Pathogens Transmitted Commonly Through Food --- 10 States, 2006. MMWR , 56, 336-339.

Chen C Y, Wu K M, Chang Y C, Chang C H, Tsai H C, Liao T L, Liu Y M, Chen H J, Shen A T, Li J C, Su T L, Shao C P, Lee C T, Hor L I and Tsai S F (2003), Comparative genome analysis of Vibrio vulnificus, a marine pathogen. Genome Res, 13, 2577-2587.

Chowdhury N R, Chakraborty S, Eampokalap B, Chaicumpa W, Chongsa-Ngun M, Moolasrt P, Mitra R, Ramamurty T, Bhattacharya S K, Nishibuchi M, Takeda Y and Nair GB (2000), Clonal dissemination of Vibrio parahaemolyticus displaying similar DNA fingerprint but 
belonging to two different serovars (O3:K6 and O4:K68) in Thailand and India, Epidemiol Infect, 125, 17-25.

Colodner R, Raz, R, Meir I, Lazarovich T, Lerner L, Kopelowitz, J, Keness Y, Sakran W, Ken-Dror S and Bisharat N (2004), Identification of the emerging pathogen Vibrio vulnificus biotype 3 by commercially available phenotypic methods. J Clin Microbiol, 42, 4137-4140.

Cook D W, O’Leary P, Hunsucker J C, Sloan E M, Bowers J C, Blodgett R J and DePaola A (2002), Vibrio vulnificus and Vibrio parahaemolyticus in USA retail shell oysters : A national survey June 1998 to July 1999, J Food Prot, 65, 79-87.

Cordova J L, Astorga J, Silva W and Riquelme C (2002), Characterization by PCR of Vibrio parahaemolyticus isolates collected during the 1997-1998 Chilean outbreak, Biol Res, 35, 433-40.

Coutard F, Pommepuy M, Loaec S and Hervio-Heath D (2005), mRNA detection by reverse transcription-PCR for monitoring viability and potential virulence in a pathogenic strain of Vibrio parahaemolyticus in viable but nonculturable state, J Appl Microbiol , 98, 951-61.

Croci L., Serratore P, Cozzi L, Stacchini A, Milandri S, Suffredini E and Toti L (2001), Detection of Vibrionaceae in mussels and in their seawater growing area, Microbiologie Aliments - Nutrition, 14, 161-165. 
Croci L, Suffredini E, Cozzi L and Toti L (2002), Effects of depuration of molluscs experimentally contaminated with Escherichia coli, Vibrio cholerae O1, and Vibrio parahaemolyticus. J Appl Microbiol, 92, 460-465.

Croci L, Delibato E, Volpe G, De Medici D and Palleschi G (2004), Comparison of PCR, electrochemical ELISA and the standard cultural method for detecting Salmonella spp in meat products, Appl Environ Microb, 70, 1393-1396.

Croci L, Suffredini E, Cozzi L, Toti L, Ottaviani D, Pruzzo C, Serratore P, Fischetti R, Goffredo E, Loffredo G, Mioni R and Vibrio parahaemolyticus Working Group (2007), Comparison of different biochemical and molecular methods for the identification of Vibrio parahaemolyticus, J Appl Microb, 102, 229-237.

Croci L, Suffredini E, Cozzi L, Paniconi M, Ciccaglioni G and Colombo MM (2006), Effectiveness of different PCR methods for the identification of Vibrio parahaemolyticus to species level, $J$ AOAC Int (in press).

Crum N F (2002), Update on Listeria monocytogenes infection, Curr Gastroenterol Rep, 4, 287-296.

Dalsgaard A, Dalsgaard I, Hoi L and Larsen J L (1996), Comparison of a commercial biochemical kit and an oligonucleotide probe for identification of environmental isolates of Vibrio vulnificus, Lett Appl Microbiol, 22, 184-188. 
Dalsgaard A, Frimodt-Moller N, Bruum B, Hoi L and Larsen J L (1996), Clinical manifestations and molecular epidemiology of Vibrio vulnificus infections in Denmark, Eur J Clin Microbiol Infect Dis, 15, 227-232.

Deepanjali A, Kumar H S, Karunasagar I and Karunasagar I (2005), Seasonal variation in abundance of total and pathogenic Vibrio parahaemolyticus bacteria in oysters along the southwest coast of India, Appl Environ Microbiol, 71, 3575-3580.

Del Mar Lleo M, Pierobon S, Tafi M C, Signoretto C and Canepari P (2000), mRNA detection by reverse transcription-PCR for monitoring viability over time in an Enterococcus faecalis viable but nonculturable population maintained in a laboratory microcosm, Appl Environ Microbiol, 66, 4564-4567.

DePaola A, Hopkins L H, Peeler J T, Wentz B and McPhearson R M (1990), Incidence of Vibrio parahaemolyticus in U.S. coastal waters and oysters, Appl Environ Microbiol, 56, 2299-2302.

DePaola A, Kaysner C A, Bowers J and Cook D W (2000), Environmental investigations of Vibrio parahaemolyticus in oysters after outbreaks in Washington, Texas, and New York (1997 and 1998), Appl Environ Microbiol, 66, 4649-4654.

ECFF (1999), European Chilled Food Federation Guidelines. Appendix C. Lethal rates for psychrotrophic Clostridium botulinum Type B. (6/8/01). 
Eom H S, Hwang B H, Kim D H, Lee I B, Kim Y H and Cha H J (2006), Multiple detection of food-borne pathogenic bacteria using a novel 16S rDNA-based oligonucleotide signature chip, Biosens Bioelectron, Article in press.

European Commission (2001), Vibrio parahaemolyticus and Vibrio vulnificus in raw and undercooked seafood. Report by the EU Scientific Committee on Veterinary Measures Relating to Public Health.

European Communities (2005) Commission Regulation (EC) No 2073/2005 on microbiological criteria for foodstuffs, Off J Eur Communities, L338 22.12.05, 1-26.

FAO/WHO (2005a), Risk assessment of Vibrio vulnificus in raw oysters. Interpretative summary and technical report. Microbiological Risk Assessment Series (FAO/WHO). 17265274, no. 8. Rome:FAO/WHO.

FAO/WHO (2005b), Risk assessment of choleragenic Vibrio cholerae O1 and O139 in warm-water shrimp in international trade. Interpretative summary and technical report. Microbiological Risk Assessment Series (FAO/WHO). 1726-5274, no. 8. Rome:FAO/WHO.

FDA (2003), Quantitative Assessment of Relative Risk to Public Health from Foodborne Listeria monocytogenes Among Selected Categories of Ready-to-Eat Foods. Food and Drug Administration, Center for Food Safety and Applied Nutrition, Office of Seafood, Washington, DC. 
FDA (2004), Bacteriological Analytical Manual. Chapter 9, Vibrio. Food and Drug

Administration, Center for Food Safety and Applied Nutrition, Office of Seafood, Washington, DC.

FDA (2005), Quantitative Risk Assessment on the Public Health Impact of Pathogenic Vibrio parahaemolyticus in Raw Oysters. Food and Drug Administration, Center for Food Safety and Applied Nutrition, Office of Seafood, Washington, DC.

FDA. (2006), Pathogen survival through pasteurization. Ch. 17. In Fish and Fishery Products Hazards and Controls Guidance, $3^{\text {rd }}$ ed., p. 219-226. Food and Drug Administration, Center for Food Safety and Applied Nutrition, Office of Seafood, Washington, DC.

Fischer-Le Saux M, Hervio-Heath D, Loaec S, Colwell R R and Pommepuy M (2002), Detection of cytotoxin-hemolysin mRNA in nonculturable populations of environmental and clinical Vibrio vulnificus strains in artificial seawater, Appl Environ Microbiol, 68, 56415646.

Flemming L E, Broad K, Clement A, Dewailly E, Elmir S, Knap A, Pomponi S A, Smith S, Solo Gabriele H and Walsh P (2006), Oceans and human health: Emerging public health risks in the marine environment, Marine Pollution Bulletin, 53, 545-560.

Gillespie I A, Adak G K, O'Brien S J, Brett M M and Bolton F J (2001), General outbreaks of infectious intestinal disease associated with fish and shellfish, England and Wales, 19921999, Commun Dis Public Health, 4 (2), 117-23. 
Gonzalez S F, Krug, M.J, Nielsen M E, Santos Y and Call D R (2004), Simultaneous detection of marine fish pathogens by using multiplex PCR and a DNA microarray, J Clin Microbiol, 42, 1414-1419.

Gould G W (1999), Sous vide foods: conclusions of an ECFF botulinum working party, Food Control, 10, 47-51.

Greenwood M, Winnard G and Bagot B (1998), An outbreak of Salmonella enteritidis phage type 19 infection associated with cockles, Commun Dis Public Health, 1, 35-7.

Grimont P A D and Grimont F (1991), rRNA probes as tools for molecular epidemiology of microbial infections, in Vaheri A, Tilton R C and Balows A (Eds), Rapid Methods and Automation in Microbiology and Immunology, Springer-Verlag, Berlin, 47-53.

Guschin D.Y., Mobarry B K, Proudnikov D, Stahl D A, Rittermann B E and Mirzabekov, A D (1997), Oligonucleotide microchips as genosensors for determinative and environmental studies in microbiology, Appl Environ Microbiol, 63, 2397-2402.

Hervio-Heath D, Colwell R R, Derrien A, Robert-pillot A, Fournier J M and Pommepuy M (2002), Occurrence of pathogenic vibrios in coastal areas of France, J Appl Microbiol, 92, 1123-1135.

Hill W E (1996), The polymerase chain reaction: applications for the detections of foodborne pathogens, Crit Rev Food Sci, 36, 123-173. 
Høi L, Dalsgaard A, Larsen J L, Warner J M and Oliver J D (1997), Comparison of ribotyping and randomly amplified polymorphic DNA PCR for characterisation of Vibrio vulnificus, Appl Environ Microbiol, 63, 1674-1678.

Hyytia E, Bjorkroth J, Hielm S, and Korkeala H (1999), Characterisation of Clostridium botulinum groups I and II by randomly amplified polymorphic DNA analysis and repetitive element sequence-based PCR, Int J Food Microbiol, 48, 179-189.

Huss H, Ababouch L and Gram L (2004), Assessment and management of seafood safety and quality. FAO, Rome

Israil A M, Balotescu C and Alexandru I (2003), [Comparative study of classical and commercial microtest API galleries in the diagnosis of cholera infection], Bacteriol Virusol Parazitol Epidemiol, 48, 145-148.

Jaykus L A (2003), Challenges to developing real-time methods to detect pathogens in foods, ASM News, 69, 341-347.

Jin L Q, Li J W, Wang S Q, Chao F H, Wang S W and Yuan Z Q (2005), Detection and identification of intestinal pathogenic bacteria by hybridization to oligonucleotide microarrays. World J Gastroenterol, 11, 7615-9.

Johansson T, Rantala L, Palmu L, Honkanen - Buzalski T (1999), Occurrence and typing of Listeria monocytogenes strains in retail vacuum-packed fish products and in a production plant, Int J Food Microbiol, 47,111-119. 
Johnston D E, Farmer L J, Dynes C, and Rutherford J A (2003), High pressure processing of mussels, oysters and prawns, Conference, Pressure to Succeed-an Insight into High Pressure Food Processing, Ireland, 9 April 2003.

Jones, S H, Howell T L, O’Neill K R and Langan R (1995), Strategies for removal of indicator and pathogenic bacteria from commercially harvested shellfish. In Shellfish purification. Proceedings of the Second International Conference on Shellfish Purification - Rennes 6-8 April 1992, Poggi R and Le Gall J-Y (Eds), Plouzané, IFREMER, 69-77.

Kam K M, Luy C K Y, Tsang Y M, Law C P, Chu M Y, Cheung T L and Chiu A W H (2003), Molecular subtyping of Vibrio cholerae O1 and O139 by pulse field gel electrophoresis in Hong Kong: Correlation with epidemiological events from 1994-2002, J Clin Microbiol, 41, 4502-4511.

Kaper J B, Lockman H, Colwell R R and Joseph S W (1979), Ecology, serology, and enterotoxin production of Vibrio cholerae in Chesapeake Bay, Appl Environ Microbiol, 37, 91-103.

Kim Y B, Okuda J, Matsumoto C, Takahashi N, Hashimoto S and Nishibuchi M (1999), Identification of Vibrio parahaemolyticus strains at the species level by PCR targeted to the toxR gene, J Clin Microbiol, 37, 1173-1177.

Khan A A, McCarthy S, Wang R F and Cerniglia C E 2002, Characterization of United States outbreak isolates of Vibrio parahaemolyticus using enterobacterial repetitive intergenic 
consensus (ERIC) PCR and development of a rapid PCR method for detection of 03:K6 isolates, FEMS Microbiol Lett, 206, 209-214.

Klein P G and Juneja V K (1997), Sensitive detection of viable Listeria monocytogenes by reverse transcription-PCR, Appl Environ Microbiol, 63, 4441-4448.

Kumao T, Ba-Thein W and Hayashi H (2002), Molecular Subtyping Methods for Detection of Salmonella enterica Serovar Oranienburg Outbreaks. J Clin Microbiol, 40, 2057-2061.

Lee C Y, Pan S F and Chen C H (1995), Sequence of a cloned pR72H fragment and its use for detection of Vibrio parahaemolyticus in shellfish with the PCR, Appl Environ Microbiol, $61,1311-1317$.

Lee C Y, Panicker G and Bej A K (2003), Detection of pathogenic bacteria in shellfish using multiplex PCR followed by CovaLinkTM NH microwell plate sandwich hybridization. $J$ Microbiol Meth, 53, 199-209.

Lin Z, Kumagai K, Baba K, Mekalanos J J and Nishibuchi M (1993), Vibrio parahaemolyticus has a homolog of the Vibrio cholerae toxRS operon that mediates environmentally induced regulation of the thermostable direct hemolysin gene, J Bacteriol, 175, 3844-3855.

Lu P L, Chang S C, Pan C M H J L and. Luh K T (2001), Application of pulsed-field gel electrophoresis to the investigation of a nosocomial outbreak of Vibrio parahaemolyticus, $J$ Microbiol, Immunol Infect (Taiwan), 33, 29-33. 
Marshall S, Clark C G, Wang G, Mulvey M, Kelly M T and Johnson W (1999), Comparison of molecular methods for typing Vibrio parahaemolyticus, J Clin Microbiol, 37 (8), 24732478.

Martinez-Urtaza J, Lozano-Leon A, DePaola A, Ishibashi M, Shimada K, Nishibuchi M and Liebana E (2004), Characterization of pathogenic Vibrio parahaemolyticus isolates from clinical sources in Spain and comparison with Asian and North American pandemic isolates, J Clin Microbiol, 42 (10), 4672-4678.

Martinez-Urtaza J, Saco M, Novoa J, Perez-Pineiro P, Peiteado J, Lozano-Leon A and Garcia-Martin O (2004), Influence of environmental factors and human activity on the presence of salmonella serovars in a marine environment, Appl Environ Microbiol, 70, 20892097.

Martinez-Urtaza J, Lozano-Leon A, Vina-Feas A, de Novoa J and Garcia-Martin O (2006), Differences in the API 20E biochemical patterns of clinical and environmental Vibrio parahaemolyticus isolates, FEMS Microbiol Lett, 255, 75-81.

Martinez I, James D and Loréal H (2005) Application of modern techniques to ensure seafood safety and authenticity. FAO Fisheries Technical Paper no. 455, Rome, UN Food and Agriculture Office.

Matches J and Liston J (1971), Radiation destruction of Vibrio parahaemolyticus, J Food Sci, 36 (2), 339-340. 
Maslow J and Mulligan ME (1996), Epidemiologic typing systems, Infect Control Hosp Epidemiol, 17, 595-604.

McCarthy S A, DePaola A, Cook DW, Kaysner C A and Hill W E (1999), Evaluation of alkaline phosphatase- and digoxigenin-labelled probes for detection of the thermolabile hemolysin (tlh) gene of Vibrio parahaemolyticus, Lett Appl Microbiol, 28, 66-70.

Meer R R and Park D L (1995), Immunochemical detection methods for Salmonella spp, Escherichia coli O157:H7 and Listeria monocytogenes in foods, Rev Environ Contam Toxicol, 142, 1-12.

Miettinen H (2006), Listeria monocytogenes in fish farming and processing, Doctoral dissertation, University of Helsinki, Helsinki.

Miwa N, Kashiwagi M, Kawamori F, Masuda T, Sano Y, Hiroi M and Kurashige H (2006), Levels of Vibrio parahaemolyticus and thermostable direct hemolysin gene-positive organisms in retail seafood determined by the most probable number-polymerase chain reaction (MPN-PCR) method, Shokuhin Eiseigaku Zasshi , 47, 41-45.

Molins R A, Motarjemi Y and Kaferstein F K (2001), Irradiation: a critical control point in ensuring the microbiological safety of raw foods, Food Control, 12, 347-356.

Motes M L and DePaola A (1996), Offshore suspension relay to reduce levels of Vibrio vulnificus in oysters (Crassostrea virginica), Appl Environ Microbiol, 62, 3875-3877. 
Murchie L W, Cruz-Romero M, Kerry J P, Linton M, Patterson M F, Smiddy M and Kelly A L (2005), High pressure processing of shellfish: A review of microbiological and other quality aspects, Innovative Food Science \& Emerging Technologies, 6, 257-270.

Myers M L, Panicker G and Bej A K (2003), PCR Detection of a newly emerged pandemic Vibrio parahaemolyticus O3:K6 pathogen in pure cultures and seeded waters from the Gulf of Mexico, Appl Environ Microbiol, 69, 2194-2200.

Nasu H, Iida T, Sugahara H, Yamaguchi Y, Park K S, Yokoyama K, Makino K, Shinagawa H and Honda T (2000), A filamentous phage associated with recent pandemic Vibrio parahaemolyticus O3:K6 strains, J Clin Microbiol, 8, 2156-2161.

Nelson E J, Tunsjø H S, Fidopiastis P M, Sørum H and Ruby E G (2007), A novel lux operon in the cryptically bioluminescent fish pathogen Vibrio salmonicida is associated with virulence, Appl Environ Microbiol, 73, 1825-1833.

Nishibuchi M and Kaper J B (1995), Thermostable direct haemolysin gene of Vibrio parahaemolyticus: a virulence gene acquired by a marine bacterium, Infect Immun, 63, 20932099.

O'Brien S J, Elson R, Gillespie I A, Adak G K and Cowden J M (2002), Surveillance of foodborne outbreaks of infectious intestinal disease in England and Wales 1992-1999: contributing to evidence-based food policy?, Public Health, 116 (2), 75-80. 
O'Hara C M, Sowers E G, Bopp C A, Duda S B and Strockbine N A (2003), Accuracy of six commercially available systems for identification of members of the family Vibrionaceae, $J$ Clin Microbiol, 41, 5654-5659.

Oliver J D and Kaper J B (1997), ‘Vibrio species’, in Doyle M P, Beuchat L R. and Montville T J (Eds), Food Microbiology - Fundamentals and Frontiers, Washington D C, ASM Press, 228-264

Ottaviani D, Masini L and Bacchiocchi S (2003), A biochemical protocol for the isolation and identification of current species of Vibrio in seafood, J Appl Microbiol, 95, 1277-1284.

Panicker G, Call D R, Krug M J and Bej A K (2004), Detection of pathogenic Vibrio spp. in shellfish by using multiplex PCR and DNA microarrays, Appl Environ Microbiol, 70 (12), 7436-7444.

Panicker G, Vickery M C L and Bej A K (2004), Multiplex PCR detection of clinical and environmental strains of Vibrio vulnificus in shellfish, Can J Microbiol, 50 (11), 911-922.

Ripabelli G, Sammarco M L, McLauchlin J and Fanelli I (2003), Molecular characterisation and antimicrobial resistance of Vibrio vulnificus and Vibrio alginolyticus isolated from mussels (Mytilus galloprovincialis), System Appl Microbiol, 26, 119-126.

Robert-Pillot A, Guenole A and Fournier J M (2002), Usefulness of R72H PCR assay for differentiation between Vibrio parahaemolyticus and Vibrio alginolyticus species: validation by DNA-DNA hybridisation, FEMS Microbiol Lett, 215, 1-6. 
Robert-Pillot A, Guénolé A, Lesne J, Delesmont R, Fournier J M and Quilici M L (2004), Occurrence of the $t d h$ and trh genes in Vibrio parahaemolyticus isolates from waters and raw shellfish collected in two French coastal areas and from seafood imported into France, $J$ Food Microbiol, 91, 319-325.

Rocourt J, Hof H, Schrettenbrunner A et al. (1986), Meningite purulente aigue a Listeria seeligeri chez un adult immunocompetent, Schweiz Med Wsch, 116, 248-251.

Rowse A J and Fleet G H 1982, Viability and Release of Salmonella charity and Escherichia coli from Oyster Feces, Appl Environ Microbiol, 44, 544-548.

Sheridan G E C, Masters C I, Shallcross J A and Mackey B M (1998), Detection of mRNA by reverse transcription-PCR as an indicator of viability in Escherichia coli cells, Appl Environ Microbiol, 64, 1313-1318.

Streulens M J (1998), Molecular epidemiologic typing systems of bacterial pathogens: current issues and perspectives, Mem Inst Oswaldo Cruz Rio de Janeiro, 93, 581-585.

Sumner J and Ross T (2002), A semi-quantitative seafood safety risk assessment, Int J Food Microbiol, 77, 55-59.

Tada J, Ohashi T, Nishimura N, Hirasaki Y, Ozaki H, Fukushima S, Takano J, Nishibuchi M and Takeda Y 1992, Detection of thermostable direct hemolysin-related hemolysin gene (trh) of Vibrio parahaemolyticus by polymerase chain reaction, Mol Cell Probes, 6, 477-487. 
Takahashi J, Hara-Kudo J, Miyasaka J, Kumagai S and Konuma H (2005), Development of a quantitative real-time polymerase chain reaction targeted to the toxR for detection of Vibrio vulnificus, J Microbiol Meth, 61 (1), 77-85.

Takahashi J, Iwabe Y, Konuma H, and Hara-Kudo J (2005), Development of a quantitative real-time PCR method for estimation of the total number of Vibrio parahaemolyticus in contaminated shellfish and seawater, J Food Protect, 68 (5), 1083-1088.

Tamplin M L, Jackson J K, Buchrieser C, Murphree R L, Portier K M, Gangar V, Miller L G and Kaspar C W (1996), Pulsed-field gel electrophoresis and ribotype profiles of clinical and environmental Vibrio vulnificus isolates, Appl Environ Microbiol, 62,3572-3580.

Tamplin M L, Rodrick G E, Blake J and Cuba T (1982), Isolation and characterization of Vibrio vulnificus from two Florida estuaries, Appl Environ Microbiol, 44, 1466-1470.

Taniguchi H, Hirano H, Kubomura S, Higashi K and Mizuguchi Y (1986), Comparison of the nucleotide sequences of the genes for the thermostable direct hemolysin from Vibrio parahaemolyticus, Microb Pathog,1, 425-432.

Tarr C L, Patel J S, Puhr N D, Sowers E, Bopp C A and Strockbine N A (2006), Identificaton of Vibrio isolates using a multiplex PCR assay and $r p o B$ sequence determination, J Clin Microbiol, Article in press. 
Tenover F C, Arbeit R D, Goering R V, the Molecular Typing Working Group of the Society for Healthcare Epidemiology of America (1997), How to select and interpret molecular typing methods for epidemiological studies of bacterial infections: a review for healthcare epidemiologists., Infect Cont Hosp Ep,18, 426-439.

Teophilo G N, Vierira D F, Rodrigues D P and Menezes F G (2002), Escherichia coli isolated from seafood: toxicity and plasmid profiles, Int Microbiol, 5, 11-14.

Timoney J F and Abston A (1984), Accumulation and elimination of Escherichia coli and Salmonella typhimurium by hard clams in an in vitro system, Appl Environ Microbiol, 47, 986-988.

Todd E C D (1997), Epidemiology of foodborne diseases: a worldwide review. Rapp trimest statist sanit mond, 50, 30-50.

Toti L, Croci L, Serratore P, Stacchini A, Milandri S and Cozzi L (1996), Bacteria isolated from seawater and mussels: identification and toxin production, Lett Appl Microbiol, 32, 5761.

Towner K J and Cockayne A (1993), Molecular Methods for Microbial Identification and Typing, London ; New York : Chapman \& Hall.

Truu J, Talpsep E, Heinaru E, Stottmeister U, Wand H and Heinaru A (1999), Comparison of API 20NE and Biolog GN identification systems assessed by techniques of multivariate analyses, J Microbiol Meth, 36, 193-201. 
US FDA 2004. Bacteriological Analytical Manual Online. Chapter 9 Vibrio, http://www.cfsan.fda.gov/ ebam/bam-9.html.

Vaneechoutte M and Van Eldere J (1997), The possibilities and limitations of nucleic acid amplification technology in diagnostic microbiology, J Med Microbiol, 46, 188-194.

Venkateswaran K, Dohmoto N and Harayama S (1998) Cloning and nucleotide sequence of the gyrB gene of Vibrio parahaemolyticus and its application in detection of this pathogen in shrimp, Appl Environ Microbiol, 64, 681-687.

Versalovic J, Koeuth T and Lupski J R 1991, Distribution of repetitive DNA sequences in eubacteria and application to fingerprinting of bacterial genomes, Nucleic Acids Res, 19, 6823-6831.

Voisin E (2001), United States Patent 6427435. Process elimination of bacteria in shellfish and of shucking shellfish, Issued $17^{\text {th }}$ April 2001.

Voisin E. (2002) United States Patent 6426103. Process elimination of bacteria in shellfish and of shucking shellfish, Issued $30^{\text {th }}$ July 2002.

Vora G J, Meador C E, Bird M M, Bopp C A, Andreadis J D and Stenger D A (2005), Microarray-based detection of genetic heterogeneity, antimicrobial resistance, and the viable but nonculturable state in human pathogenic Vibrio spp, Proc Natl Acad Sci USA, 102, 19109-19114. 
Ward D R and Baj N J (1988), Factors affecting the microbiological quality of seafoods, Food Technol, 42, 85-89.

Warner J M and Oliver J D (1998), Randomly amplified polymorphic DNA analysis of starved and viable but nonculturable Vibrio vulnificus cells, Appl Environ Microbiol, 64, 3025-3028.

Weber J T, Mintz E D, Caizares R, Semiglia A, Gomez I, Sempertegui R, et al. (1994), Epidemic cholera in Ecuador: multidrug resistance and transmission by water and seafood, Epidemiol Infect, 112, 1-11.

West P A (1989), Human pathogens and public health indicator organisms in shellfish, in Austin B and Austin D A (Eds), Methods for the microbiological examination of fish and shellfish, Chichester, Ellis Horwood Ltd, 273-308.

Wittman R J and Flick G J (1995), Microbial contamination of shellfish: prevalence, risk to human health, and control strategies, Ann Rev Publ Health, 16, 123-140.

Wong $\mathrm{H}$ and Lin C (2001), Evaluation of typing of Vibrio parahaemolyticus by three PCR methods using specific PCR, J Clin Microbiol, 39, 4233-4240.

Wong H C, Ho C Y, Kuo L P, Wang T K, Lee C L and Shih D Y (1999), Ribotyping of V. parahaemolyticus isolates obtained from food poisoning outbreaks in Taiwan, Microbiol Immunol, 43, 631-636. 
Wu M S and Lee C Y (1998),.Sequence analysis of the flanking regions of Vibrio parahaemolyticus R72H fragment, 98th General Meeting of the American Society for Microbiology, Atlanta, GA.

Younger A D, Lee R J and Lees DN (2003), Microbiological monitoring of bivalve mollusc harvesting areas in England and Wales - rationale and approach, in Villalba, A, Reguera B, Romalde J L, Beiras R (Eds), Molluscan Shellfish Safety, Santiago de Compostela, Spain, Consellería de Pesca e Asuntos Marítimos da Xunta de Galicia and Intergovernmental Oceanographic Commission of UNESCO, 265-277. 